\title{
PARP Inhibitor Olaparib Causes No Potentiation of the Bleomycin Effect in VERO Cells, Even in the Presence of Pooled ATM, DNA-PK, and LigIV Inhibitors
}

\author{
Valentina Perini ${ }^{1}$, Michelle Schacke ${ }^{1}$, Pablo Liddle ${ }^{1}$, Salomé Vilchez-Larrea ${ }^{2}$, \\ Deborah J. Keszenman ${ }^{3, *}$ and Laura Lafon-Hughes $1, *$ (D) \\ 1 Instituto de Investigaciones Biológicas Clemente Estable (IIBCE), Departamento de Genética, \\ Montevideo 11.600, Uruguay; valeperini95@gmail.com (V.P.); michimefuz@gmail.com (M.S.); \\ pabloliddle@googlemail.com (P.L.) \\ 2 Instituto de Investigaciones en Ingeniería Genética y Biología Molecular "Dr. Héctor N. Torres", \\ Consejo Nacional de Investigaciones Científicas y Técnicas, Ciudad Autónoma de Buenos Aires 1428, \\ Argentina; vilchez.ingebi@gmail.com \\ 3 Laboratorio de Radiobiología Médica y Ambiental, Grupo de Biofisicoquímica, Centro Universitario \\ Regional Litoral Norte, Universidad de la República (UdelaR), Salto 50.000, Uruguay \\ * Correspondence: dkeszen@gmail.com (D.J.K.); lauralafon2010@gmail.com (L.L.-H.)
}

Received: 30 September 2020; Accepted: 19 October 2020; Published: 5 November 2020

\begin{abstract}
Poly(ADP-ribosyl)polymerase (PARP) synthesizes poly(ADP-ribose) (PAR), which is anchored to proteins. PAR facilitates multiprotein complexes' assembly. Nuclear PAR affects chromatin's structure and functions, including transcriptional regulation. In response to stress, particularly genotoxic stress, PARP activation facilitates DNA damage repair. The PARP inhibitor Olaparib (OLA) displays synthetic lethality with mutated homologous recombination proteins (BRCA-1/2), base excision repair proteins (XRCC1, Pol $\beta$ ), and canonical nonhomologous end joining (LigIV). However, the limits of synthetic lethality are not clear. On one hand, it is unknown whether any limiting factor of homologous recombination can be a synthetic PARP lethality partner. On the other hand, some BRCA-mutated patients are not responsive to OLA for still unknown reasons. In an effort to help delineate the boundaries of synthetic lethality, we have induced DNA damage in VERO cells with the radiomimetic chemotherapeutic agent bleomycin (BLEO). A VERO subpopulation was resistant to BLEO, BLEO + OLA, and BLEO + OLA + ATM inhibitor KU55933 + DNA-PK inhibitor KU-0060648 + LigIV inhibitor SCR7 pyrazine. Regarding the mechanism(s) behind the resistance and lack of synthetic lethality, some hypotheses have been discarded and alternative hypotheses are suggested.
\end{abstract}

Keywords: poly(ADP-ribosylation); PARP-1; Olaparib; KU55933; KU-0060648; SCR7 pyrazine; VERO cells; synergism; resistance; CDKN2A

\section{Introduction}

Poly(ADP-ribosylation) or PARylation is a post-translational protein modification that is catalyzed by poly(ADP-ribosyl)polymerases (PARPs). PARPs consume nicotinamide adenine dinucleotide (NAD+) and release nicotinamide (Nam) every time they add ADP-ribose monomers to originate a lineal or ramified chain of up to 400 residues that is covalently anchored to a single amino acid. Such a nucleic-acid-like polymer, called poly(ADP-ribose) or PAR, is strongly negatively charged since it harbors two phosphate groups per residue. PAR is recognized by PAR-binding protein domains (e.g., a macrodomain) and facilitates the assembly of multiprotein complexes through 
non-covalent interactions. For this reason, PAR has been called a "glue" [1]. PAR synthesis is stimulated by genotoxic insults, increasing up to 500 times overall or 7 to 8 times on specific proteins [2,3].

Both endogenous metabolism and exogenous genotoxic agents induce different types of DNA damage, such as oxidative lesions, single-base modifications, crosslinks, local changes in DNA structure, single-strand breaks (SSBs), and double-strand breaks (DSBs), which can be repaired by different DNA repair systems while the cell cycle is coordinately slowed down. Directly or indirectly generated DSBs are the most challenging type of DNA damage for the cell because they can lead to mutations, carcinogenesis, or cell death. DSBs are marked by the spread of the phosphorylation of the histone H2AX on Ser139 by the canonical kinases ATM, ATR, or DNA-PK [4] through a feed-forward signaling loop to give $\gamma \mathrm{H} 2 \mathrm{AX}$ foci. A less studied chromatin-bound kinase called VRK1 can also give rise to $\gamma \mathrm{H} 2 \mathrm{AX}$ foci, at least in response to DNA damage induced by $\gamma$-rays [5]. Lesions are then repaired either after DNA replication by homologous recombination (HR) or throughout the cell cycle by canonical nonhomologous end-joining (c-NHEJ) or alternative NHEJ, also called microhomology-mediated end joining (MMEJ). Unrepaired damage may lead to replication fork stalling and single-stranded DNA exposure, activating ATR [6]. Regarding genomic stability, it is accepted that HR is the DSBs repair pathway that allows for the highest fidelity, MMEJ is the one promoting the highest genomic instability, and c-NHEJ is in between. C-NHEJ repair occurs with a half-time of 10-30 min after damage, while MMEJ processing has a half-time of $30 \mathrm{~min}$ to $20 \mathrm{~h}$, being considered a rescue pathway [7]. Some molecular actors have been identified in each pathway. C-NHEJ is dependent on KU70/80, DNA-PK, and LigIV. C-NHEJ is promoted by 53BP1 and antagonized by BRCA1. In contrast, DNA end-resection by MRE11 exonuclease activity prevents c-NHEJ and promotes HR with BRCA-1 and BRCA-2 recruitment (in the presence of an undamaged template) or allows for MMEJ. The latter does not involve DNA-PK, 53BP1, or LigIV but is dependent on LigIII instead. These pathways are quite complex and MMEJ is still poorly understood [7-9].

The PARP family has 18 members in humans. Some of them are enzymatically inactive; others act just as mono-(ADP-ribosyl) transferases and, to our knowledge, only four of them synthesize PAR [10], namely, the canonical ancient PARP-1, PARP-2, and two tankyrases (TNKS-1 and TNKS-2). PARP-1 is the most studied member of the family and is involved in the PARP response to stress, inflammation, or genotoxic insults [11,12].

The interpreted role for PARP-1 in the DNA damage response (DDR) has changed over time in the literature. In the 20 years between 1985 and 2005, there were enthusiastic positive results with PARP inhibitors (PARPis). In different human and rodent normal or transformed cell types, diverse PARPis (3AB, INO1001, E7016, AG14361, 4-ANI) applied before, during, or after DNA damage induction sensitized cells to different genotoxic agents, including ultraviolet- $C$ radiation (UV-C), methylmethanosulfonate (MMS), ionizing radiation (IR), and the radiomimetic agent bleomycin (BLEO) [13-24]. The variable sensitization effects, i.e., additive or synergistic, suggested different biological interpretations and putative clinical implications [25]. Still, this data was promising at least as a way to reduce chemotherapy doses and consequently diminish side effects. Such results did also push the field to go on and try to understand the mechanisms involved.

Interestingly, nowadays, a paradigm shift has occurred. The current synthetic lethality paradigm states that PARPis do not appreciably affect normal cells but do potentiate DNA damage effects in cells that have certain DNA repair pathways that are blocked by the alteration (by mutation or enzymatic inhibition) of a crucial actor of the pathway. This paradigm has huge clinical implications, opening the possibility that PARPis could be used to selectively kill aberrant cells while keeping normal cells. In fact, it was under this paradigm that Olaparib (OLA, Lynparza, AZD-2281) reached U.S. Food and Drug Administration (FDA) approval to treat BRCA-1 mutated cancers (ucm572143, ucm592357, and NCT02987543). Interestingly, BRCA-1 is not only crucial for HR but also regulates BER [26,27], and OLA displays synthetic lethality with mutated BER proteins, such as XRCC1 or Pol $\beta[28,29]$ and with mutated LigIV in c-NHEJ [30]. Last but not least, PARPis can affect not only DNA repair but also modulate gene transcription [31]. In fact, the potential clinical impact of 
PARPis is not limited to cancer therapy but also reaches many pathologies that are characterized by inflammation [11,32-34]. Interestingly, the major constraint of anti-cancer BLEO therapy is the early inflammation of lung parenchyma, leading to pulmonary fibrosis [35]. Thus, we reasoned that PARPis might concomitantly potentiate BLEO-directed effects in DNA-repair-hampered cells while diminishing inflammation-related side effects in normal cells.

Not only PARP-1 but also PARP-2 [36-38], the mono(ADP-ribosyl)transferase PARP-3 [39-41], and TNKS [42] are involved in the cellular response to DNA damage, particularly DSBs. OLA was initially considered a potent and specific PARP- 1 inhibitor with an in vitro $\mathrm{IC}_{50}$ (ivitr-IC $\mathrm{I}_{50}$ ) of $5 \mathrm{nM} \mathrm{[43]}$. Later, an even lower $\mathrm{IC}_{50}$ was determined using full-length PARP-1 (ivitr-IC $\mathrm{I}_{50}: 1.4 \mathrm{nM}$ ), while it was demonstrated that it is also a potent PARP-2 (ivitr-IC ${ }_{50}$ : $12 \mathrm{nM}$ ) [44] and PARP-3 inhibitor (ivitr-IC $50: 4 \mathrm{nM}$ ) [41] but is not a potent TNKS-1 or TNKS-2 inhibitor (ivitr-IC $50: 1230 \mathrm{nM}$ and $2340 \mathrm{nM}$, respectively) [44]. As PARP-1, PARP-2, and PARP-3 are involved in DDR, the OLA effects include DNA repair hampering due to combined enzymatic inhibition/trapping of these enzymes $[38,41,45,46]$.

VERO is a kidney epithelial cell line from a female African green monkey. It is a challenging cell culture model to use when analyzing resistance mechanisms because it preserves an epithelial morphology but can form colonies in agar and includes a subpopulation that is BLEO-resistant, according to Terasima et al. [47]. It is not tumorigenic, except at very high passages [48]. Moreover, its genome has been studied [49]. Finally, VERO cells are infection-prone [49-51], thus allowing studies of DNA damage, inflammation, PARylation, or epithelial-to-mesenchymal transition induction in the host cell by viral, bacterial, or parasitic infections.

In the present work, we addressed the question of whether OLA would potentiate DNA damage induced by BLEO in VERO cells. As a further step, we asked whether the simultaneous inhibition of ATM, DNA-PK, and LigIV (to block at least HR and c-NHEJ) would show synthetic lethality with the OLA effect in VERO cells. It did not. A hypothesis regarding the mechanisms involved is discussed as a guide for future research.

\section{Results}

\subsection{OLA Did Not Potentiate BLEO Effects on VERO Cells}

As a BLEO treatment has to be performed in the absence of FBS, in all experiments involving BLEO (regardless of the presence or absence of inhibitors), all the cells, including those with and without BLEO, were subjected to a $45 \mathrm{~min}$ serum depletion. Therefore, all differences could be attributed to BLEO itself rather than to this short serum depletion.

Previous experiments were carried out in order to choose appropriate experimental conditions (Figure A1A-D).

Cell viability dose-response curves with BLEO alone ( $45 \mathrm{~min}$ pulses) were evaluated immediately after treatment $(\mathrm{t}=0 \mathrm{~h})$, or 24 or $72 \mathrm{~h}$ later (Appendix A Figure A1A). The BLEO toxicity increased slightly above $40 \mu \mathrm{g} / \mathrm{mL}$. Neither a BLEO concentration increase up to $500 \mu \mathrm{g} / \mathrm{mL}$ nor a treatment duration of $270 \mathrm{~min}$ (Figure A1B, evaluation $24 \mathrm{~h}$ post treatment) appreciably decreased the viability. In agreement with the report by Terasima et al. from 1972 [47], the VERO cell population was composed of a BLEO-sensitive and a BLEO-resistant subpopulation.

Experiments that involved adding the BLEO hydrolase inhibitor E-64 before (30 $\mathrm{min}$ ) and during ( $45 \mathrm{~min}$ ) BLEO treatment were carried out to exclude the possibility of the existence of this BLEO-degradative enzyme in our model (Figure A1C). The lack of an effect of E-64 indicated that the resistance was not due to the expression of BLEO hydrolase.

The toxicity of OLA alone was analyzed on VERO cells (Figure A1D). An approximately 70-80\% cell viability was preserved, even after a $400 \mathrm{nM}$ continuous 24 or $72 \mathrm{~h}$ treatment. As we wanted to analyze the specific effects on PARPs involved in DDR (PARP-1/2 and 3) and we knew that low concentrations were enough to inhibit at least PARP-1 in this cell line [43], we decided to regularly use 
$50 \mathrm{nM}$ OLA in the combined experiments. Furthermore, a $72 \mathrm{~h}$ evaluation point was considered to be the most informative one in our MTT assays.

The cell viability was then assayed (Figure 1A) after a 45 min serum depletion, without (control; $\mathrm{BLEO}=0 \mu \mathrm{g} / \mathrm{mL}$ ) or with BLEO (BLEO $=40$ or $160 \mu \mathrm{g} / \mathrm{mL}$ ), without (violet bars) or with (light blue bars) a $50 \mathrm{nM}$ OLA treatment. OLA exposure involved continuous co- and post-treatment that finished at the moment of evaluation with the MTT assay, $72 \mathrm{~h}$ post the BLEO treatment.
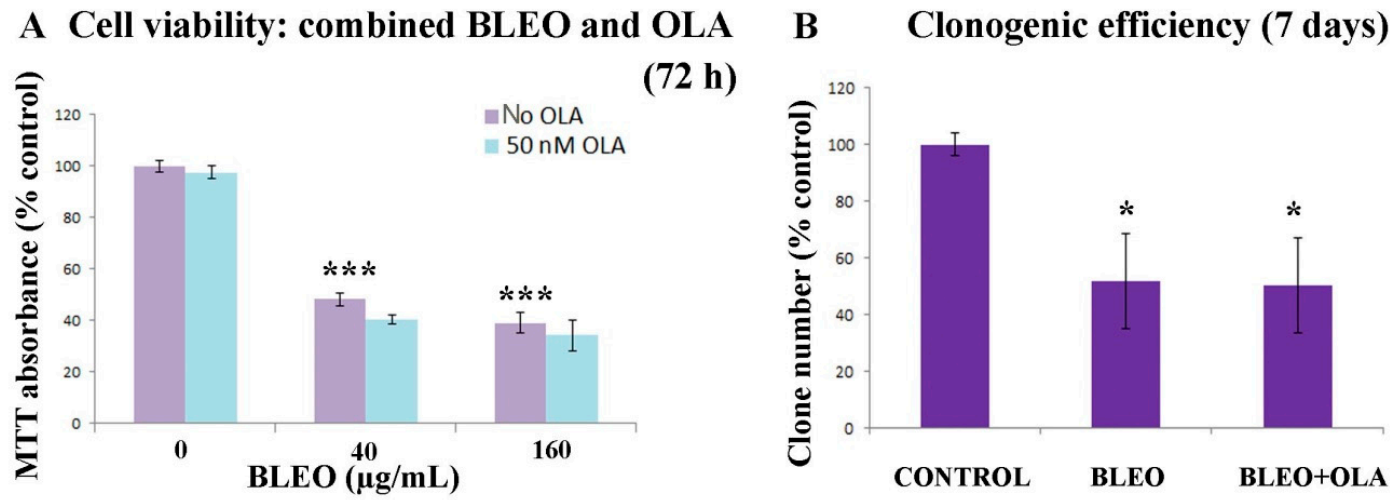

Figure 1. Neither the cell viability loss nor clonogenic efficiency loss induced by BLEO in VERO cells were potentiated by OLA. (A) Cell viability (MTT assay). Cells were exposed to BLEO and, when indicated, Co- and post-exposed to $50 \mathrm{nM}$ OLA. The result was evaluated after $72 \mathrm{~h}$. Most experiments were carried out using $40 \mu \mathrm{g} / \mathrm{mL}$ BLEO and $50 \mathrm{nM}$ OLA. The respective $n$ 's were as follows. No OLA: 63, 72, and 22; 50 nM OLA: 75, 86, and 12 (see Figure A2 for 150 nM OLA). ANOVA $\left(p=1.11 \times 10^{-16}\right)$. Post-hoc tests: Tukey, Scheffe, and Bonferroni. ${ }^{* * *}: p<0.001$. (B) Clonogenic efficiency of VERO cells in the control condition or under a pulse treatment with $40 \mu \mathrm{g} / \mathrm{mL}$ BLEO (45 $\mathrm{min}$ ) in the absence or presence of continuous treatment with 50 nM OLA. Data were from two independent experiments in triplicate. All results are expressed as mean \pm SEM. Comparisons against control. ANOVA $(p=0.0371)$ and Holm $p$-value with only comparisons against the control considered. ${ }^{*}: p<0.05$.

As shown in Figure 1A, there was no significant difference in cell viability that was attributable to $50 \mathrm{nM}$ OLA (light blue bars) in basal (BLEO $=0$ ) or BLEO-treated cells $(40$ or $160 \mu \mathrm{g} / \mathrm{mL})$.

In order to distinguish between different possible scenarios, the clonogenic efficiency was also evaluated in cells treated with BLEO $(40 \mu \mathrm{g} / \mathrm{mL})$ or BLEO + OLA (50 $\mathrm{nM})$ (Figure 1B). Two conclusions could be derived. First, taking into account the errors, cell viability results resembled clonogenic efficiencies (BLEO: 48 vs. 52\%; BLEO + OLA: 41 vs. 50\%), indicating that in the presence of $40 \mu \mathrm{g} / \mathrm{mL}$ BLEO, about one in every two cells was alive and cycling. Second, upon the OLA treatment, no difference was observed.

Although an even lower OLA concentration $(25 \mathrm{nM})$ is known to have effects on VERO nuclear PARP-1 activity [43], and $50 \mathrm{nMOLA}$ is enough to prevent or partially revert the epithelial-to-mesenchymal transition induced by TGF- $\beta$ in NMuMG cells [52], a higher OLA concentration was assayed as well, just in case an unexpected shift occurred. As can be seen in Figure A2, the OLA concentration was tripled (to $150 \mathrm{nM}$ ) and still displayed no effect on the BLEO-treated cells.

OLA did not potentiate a BLEO lethal effect in VERO cells. The absence of potentiation of the BLEO effect was also evidenced with chemically different, less specific PARPis and with a PARG inhibitor, indicating that PAR metabolism was not crucially involved in the BLEO-induced DDR. The inhibitors used were 3-aminobenzamide (3AB), 5' -deoxy-5'-[4-[2-[(2,3-dihydro-1oxo-1H-isoindol4-yl)amino]-2-oxoethyl]-1-piperazinyl]-5'-oxoadenosine dihydrochloride (EB), and 6,9-diamino-2ethoxyacridine-DL-lactate monohydrate (DEA). Figure A3A represents PAR, its synthesis by PARPs, its degradation mainly by poly-ADP-glycohydrolase (PARG), and the inhibitors abbreviations associated with their targets. Figure A3B depicts the PAR quantification on the control untreated cells and cells treated with PARPis or the PARG inhibitor DEA. As the basal PAR was low and this was done once, 
these measurements did not have much sensitivity, but overall, they were a control to check that the inhibitors were active. The lack of potentiation [25] of BLEO effects by PARPis 3AB or EB was demonstrated (Figure A3C,D). Finally, PARG inhibition did not change the cell viability in the presence of BLEO (Figure A3E,F).

To sum up, despite being able to alter the PAR metabolism, neither PARP nor PARG inhibitors potentiated the toxic effects of BLEO in VERO cells.

\subsection{Untreated VERO Cell Nuclei Harbor PARP, PARG, and PAR}

Next, it was checked whether VERO cells were expressing some of the nuclear molecular actors of PARylation, as well as synthesizing basal PAR. As displayed in Figure 2A-D, the indirect immunocytofluorescence (ICF) and DAPI (blue) counterstain showed that nuclear PARP-1/2 (green) was distributed throughout the nucleus, while the PARG (red) distribution was punctuated and excluded the nucleolus. Relative intensity measurements (Figure 2E,F) following the lines drawn in Figure 2A,B, respectively (color-coded like the channels), also supported these observations. Regardless of the distribution, the important point is that VERO cells were expressing at least PARP-1/2 and PARG. Basal PAR was also detected, as demonstrated by the comparison of Figure $2 \mathrm{H}$ vs. Figure $2 \mathrm{~K}$ and the respective relative intensity graphs (Figure $2 \mathrm{~L}, \mathrm{M}$ ).
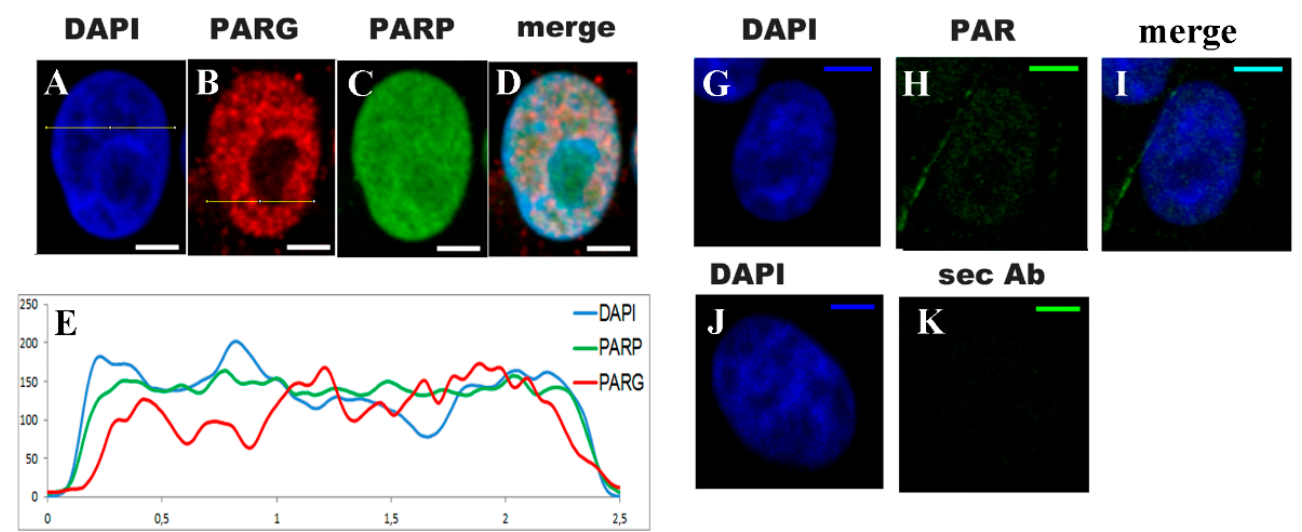

$\sec \mathbf{A b}$
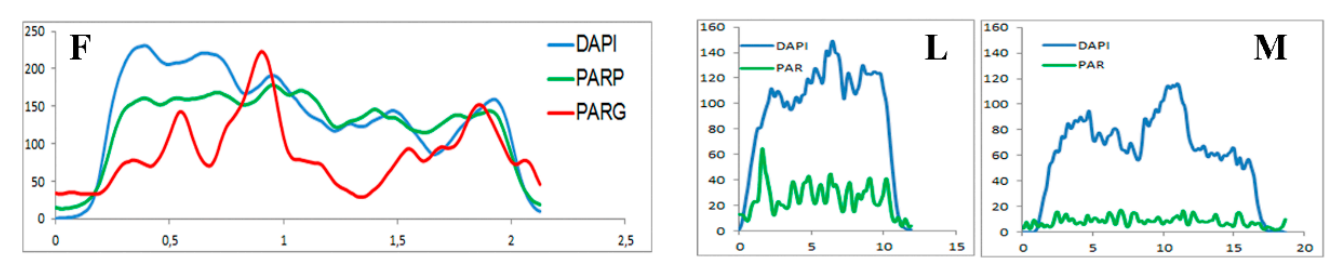

Figure 2. PAR, PARP, and PARG were detected in the VERO cell nuclei. (A-D) DAPI (blue), PARG (red), PARP (green), and the merged confocal images of representative nuclei. (E,F) Graphs displaying the fluorescence intensity measurements in the three channels of the correspondent nuclei images through two lines that are drawn in $(\mathbf{A})$ or $(\mathbf{B})$ respectively. Intensity in Relative units. Distance: $1 \mathrm{U} \approx 5 \mu \mathrm{m}$ (G-I) Indirect immunocytofluorescence (ICF) with BD anti-PAR antibody. DAPI (blue), PAR (green), and merged channels. (J,K) Control of the anti-PAR ICF without the anti-PAR antibody with only the secondary antibody ( $\sec \mathrm{Ab})$. (L,M) Blue and green channel intensities measured over a line in (H) (with anti-PAR) and (I) (without anti-PAR), respectively. Confocal images were obtained with the same settings and subject to identical processing adjustments. Relative intensity on the ordinates and distance in $\mu \mathrm{m}$ on the abscissas. PAR signal (green) was low but detectable in untreated VERO nuclei. Bar: $5 \mu \mathrm{m}$.

\subsection{No Sharp PAR Increase Could Be Detected Immediately after the 45 min Pulse of BLEO}

The first estimations in the literature suggested that PAR can increase up to 500-fold in response to a genotoxic insult [2]. Later, 50-fold increases under PARG inhibition and 7-fold increases on specific 
proteins have been reported [2,3]. To assess whether VERO cells respond to BLEO by increasing PAR levels, we performed inmunocytofluorescence experiments immediately after the end of the treatment $(t=0)$ with three different anti-PAR antibodies.

The $10 \mathrm{H}$ anti-PAR antibody has a known specificity for long PAR chains (above 20 residues) [53] and has been widely used to monitor the nuclear response to DNA damage [24,54]. Interestingly, some DDR proteins do not interact with short PAR chains (16-mer), while long PAR chains (55-mer) promote their integration into protein complexes [55]. Thus, the best antibody for detecting long-chain PAR induced by genotoxic stress is $10 \mathrm{H}$ anti-PAR. In DAPI-counterstained control or BLEO-treated ( $40 \mu \mathrm{g} / \mathrm{mL}, 45 \mathrm{~min}$ ) cells (blue, Figure $3 \mathrm{~A}-\mathrm{C}$ ), one in every several cells in the population displayed a strong nuclear PARylation signal, while the rest displayed no signal (Figure 3E; in Figure 3F, the red point under the calibration bar is a single H10-anti-PAR-positive nucleus). This observation would explain why the PAR increase in the cell population was not significant (Figure 3I, right-hand graph). As can be seen in Figure A4, a different cell type used as a positive control (CHO9 fibroblastic cell line) displayed nuclear PARylation more frequently in the same experimental conditions.
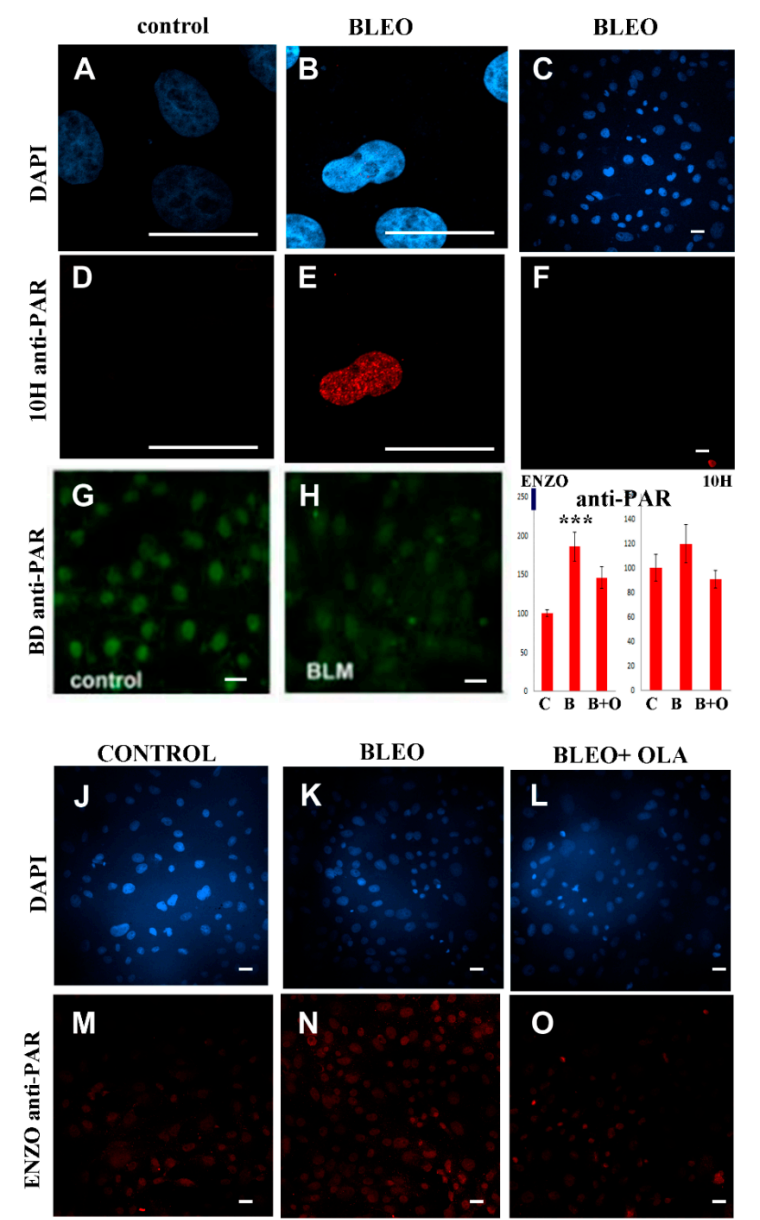

Figure 3. Neither of the three anti-PAR antibodies evidenced a sharp PAR increase using ICF immediately after the BLEO (45 $\mathrm{min}$ ) treatment. This was observed in at least five independent experiments. (A-C) DAPI channel to see nuclei that were positive or negative for the (D-F) $10 \mathrm{H}$ anti-PAR signal. $(\mathbf{A}, \mathbf{D})$ control and (B-F) BLEO. (G,H) BD anti-PAR in (G) control or (H) BLEO-treated cells. (I) To estimate the signal increase, the PAR signal intensity was quantified in one of the experiments with two of the antibodies. The whole-field PAR intensity was adjusted by the DAPI intensity and expressed as a percentage of the control. Mean \pm SEM. Left: ENZO anti-PAR. ANOVA $(p=0.0010)$. Post-hoc test: Holm against control, Tukey, or Scheffé. ${ }^{* * *}: p<0.001$. Right: $10 \mathrm{H}$ anti-PAR antibody showed no differences. $(\mathbf{J}, \mathbf{M})$ Control, $(\mathbf{K}, \mathbf{N})$ BLEO-, or $(\mathbf{L}, \mathbf{O})$ BLEO + OLA-treated cells. Panels G and $\mathbf{H}$ were extracted from Lafon-Hughes' unpublished Ph.D. thesis [56]. Bar: $25 \mu \mathrm{m}$. 
It has formerly been reported that nuclear PAR in untreated VERO cells is detected with polyclonal rabbit BD anti-PAR or chicken Tulip anti-PAR antibodies but not with Tulip monoclonal $10 \mathrm{H}$ clone antibodies [57]. Thus, now we are reporting that a third antibody detected basal nuclear PAR in VERO cells. BD and ENZO anti-PAR antibodies are better suited to detecting short-chain PAR. According to the manufacturers, ENZO anti-PAR (BML-SA216) was specifically designed against "purified poly(ADP-ribose) polymer (chain length of 2-50 units)." This would explain why no signal was detected in the control cells with $10 \mathrm{H}$ anti-PAR (Figure 3D) but there was a PAR signal in control cells with BD (Figure 3G) or ENZO anti-PAR (Figure 3M).

No signal increase was detected with BD anti-PAR in BLEO-treated cells (Figure 3H, extracted from unpublished [56]). As a positive control, a slight signal increase (about $\times 1.5$ ) was detected with BD anti-PAR only under extreme conditions leading to cell death (Figure A4). More recently, the anti-PAR reagent MABE1031 was also used to evaluate the PAR increase in response to $\mathrm{H}_{2} \mathrm{O}_{2}$, which was hampered in the presence of $50 \mathrm{nM}$ OLA (Figure A4I).

Compared to control samples (Figure 3J,M), a slight but significant PAR increase (Figure 3I) was detected with ENZO anti-PAR due to the BLEO treatment (Figure $3 \mathrm{~K}, \mathrm{~N}$ ). Of notice, given the nature of BLEO treatment, some cells may have been damaged $45 \mathrm{~min}$ before and other ones just at the very last minute before fixation. Therefore, in this single fixation, we may have had many time points that were superimposed. Regarding the effect of OLA in BLEO-treated cells (Figure 3L,O), there was a tendency toward PAR diminution. In fact, unlike what happened in BLEO-treated cells, in BLEO + OLA treated cells, the PAR level was indistinguishable from the control $(p=0.589)$. Therefore, the next step was to check that OLA was not interfering with the DNA damage induction by BLEO.

\subsection{OLA Did Not Hamper the DNA Damage Induction by BLEO}

DNA damage induction was registered in the DAPI-counterstained cells (blue, Figure 4A-C) through $\gamma \mathrm{H} 2 \mathrm{AX}$ (red, Figure 4D-F) and 53BP1 (green, Figure 4G-I) detection using ICF, as well as in cells subjected to single-cell gel electrophoresis or a comet assay (Figure 4I-K). The percentage of cells with a $\gamma \mathrm{H} 2 \mathrm{AX}$ foci (Figure 4M), the percentage of cells with a pan-nuclear $\gamma \mathrm{H} 2 \mathrm{AX}$ signal (Figure $4 \mathrm{~N}$ ), and the relative DNA damage index (DDI, Figure $4 \mathrm{O}$ ) were quantified from three independent experiments. Furthermore, in one of the experiments, the relative number of $\gamma \mathrm{H} 2 \mathrm{AX}, 53 \mathrm{BP} 1$, and mixed foci per cell was also evaluated (Figure A5). All our DNA damage induction measurements had the same stair-shape, from left to right: the control in the lower step, then BLEO, and then BLEO + OLA in the higher step. As this happened regarding the percentage of cells with $\gamma \mathrm{H} 2 \mathrm{AX}$ foci (Figure $4 \mathrm{M}$ ), the percentage of pan-nuclear $\gamma \mathrm{H} 2 \mathrm{AX}$ cells (Figure $4 \mathrm{~N}$ ), the comet DDI relative to the control (Figure 4O), and even the relative abundance of $\gamma \mathrm{H} 2 \mathrm{AX}, 53 \mathrm{BP} 1$, and mixed foci (Figure A5), it was concluded that at $t=0$, the BLEO cells were more damaged than the control cells. Moreover, the OLA undoubtedly did not interfere with BLEO to avoid the initial DNA damage induction.

\subsection{OLA Did Not Potentiate BLEO, Even in the Presence of a Pool of DNA Repair Enzyme Inhibitors}

All the data above suggested that VERO cells were repairing DSBs induced by BLEO via a mechanism that was independent of PARPs- $1 / 2$ and 3 since OLA can block their enzymatic activity or induce enzyme trapping. According to some authors [8,58], PARP-1 activation participates in MMEJ but not on HR or c-NHEJ. If this was the case, then the simultaneous block of HR and c-NHEJ should leave the cells dependent on MMEJ, thus dependent on PARP-1. Therefore, we hypothesized that the simultaneous inhibition of DNA-PK, LigIV, and ATM (3i) would either induce the death of remnant cells or force them to shift to MMEJ, thus becoming PARP-dependent and OLA-sensitive.

As depicted in the Figure 5 legend, 3 i was toxic per se (viability $=66.82 \%$ ) and BLEO + DMSO viability was $41.46 \%$. According to Webb's equation, the expected viability if the combined effect of BLEO and $3 \mathrm{i}$ was additive was $27.70 \%$. The real viability was $26.42 \pm 1.25 \%$. Thus, the $3 \mathrm{i}$ toxic effect was added to the BLEO effect. $3 \mathrm{i}$ did not potentiate the BLEO effect. 

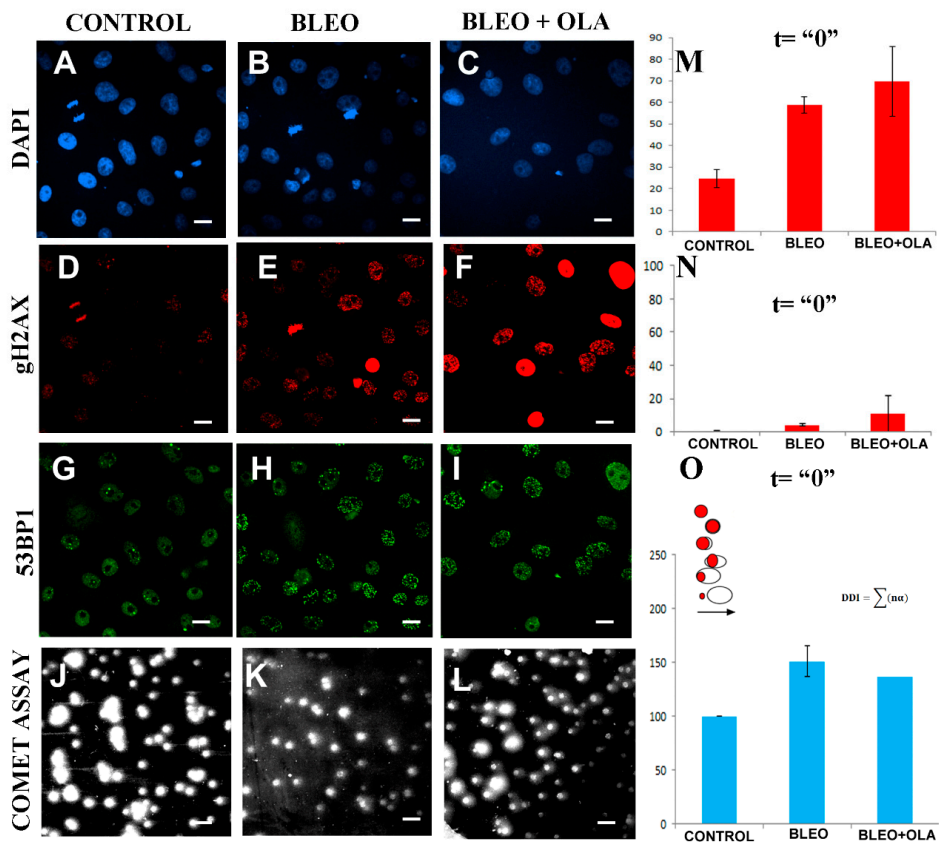

Figure 4. OLA did not hamper the DNA damage induction by BLEO. The initial $\left(\mathrm{t}={ }^{\prime \prime} 0\right.$ ") BLEO-induced DNA damage in the presence or absence of the OLA co-treatment was evaluated All images and graphs follow the order: Control, BLEO and BLEO+OLA, from left to right. (A-I) Representative ICF images. (A-C): DAPI in blue; (D-F): gH2AX in red; (G-I): 53BP1 in green. (J-L) Representative single-cell electrophoresis or comet assay images (M, in red): Percentage of cells with a $\gamma \mathrm{H} 2 \mathrm{AX}$ foci. Data were from three independent experiments and $n \geq 200$ cells/condition. Two-tailed $t$-test. ( $\mathbf{N}$, in red) Pan-nuclear $\gamma \mathrm{H} 2 \mathrm{AX}$ cells were counted on the same set of images. (O, in blue) The comet assay was evaluated using the DNA damage index (DDI). In turn, the results were normalized to control the DDI to pool the experiments. Data were from three independent experiments, with $n \geq 140$ cells/condition. Two-tailed $t$-test. $p=0.17$ (control vs. BLEO), $p=0.099$ (control vs. BLEO + OLA), $p=0.24$ (BLEO vs. $\mathrm{BLEO}+\mathrm{OLA}$ ). To calculate the DDI, each comet was assigned a degree from 1 to 5 . The inset scheme represents comet heads (in red) and comet tails (in white) for successive degrees. 1: compact or with a simetric halo (first two drawings); 2: asimetric halo; 3: tail length = head length; 4: tail length > head length; 5: head separated from tail. Bar: $20 \mu \mathrm{m}$.

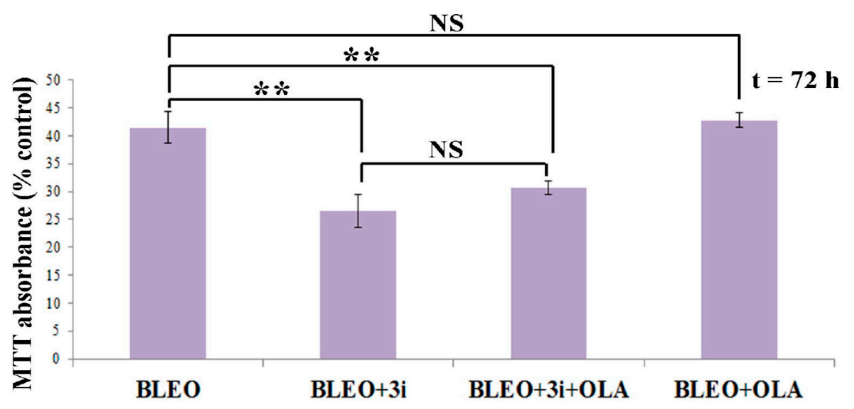

Figure 5. OLA did not potentiate the BLEO effect in VERO cells, even in the presence of certain inhibitors of DSB repair pathways. The cell viability relative to the control (MTT, $72 \mathrm{~h}$ ) of BLEO-treated cells in the absence or presence of OLA and "3i" $(0.1 \mu \mathrm{M}$ DNA-PK inhibitor KU-0060648 + 0.1 $\mu \mathrm{M}$ LigIV inhibitor SCR7 pyrazine + $5 \mathrm{mM}$ ATM inhibitor KU55933). DMSO, the inhibitors' vehicle, was maintained in a constant concentration in all conditions. Data were from six independent experiments, with $n=32,56$, 54, and 54. Mean \pm SEM. According to ANOVA and Tukey, Schaffé, or Bonferroni a posteriori tests, OLA made no difference, whereas $3 \mathrm{i}$ or $3 \mathrm{i}$ + OLA differed from the BLEO treatment with ${ }^{* *}: p<0.01$. NS: statistical non-significance. Although not represented in the graph, $3 \mathrm{i}$ was toxic by itself (cell viability $=66.82 \pm 2.9 \%$ ). 
To sum up, the unexpected results were that neither 3 i nor OLA potentiated BLEO effects on the cell viability and that most $(\approx 75 \%)$ of the cell subpopulation that resisted BLEO was still resistant in the presence of $3 \mathrm{i}$ and OLA.

\section{Discussion}

Resistance to BLEO itself in VERO cells can be due to several causes, including a low intake, high export, non-availability of free radicals (due to low Fe, hypoxia, or high antioxidant defenses) [59] or BLEO inactivation by BLEO hydrolase [60]. From these known putative causes, hypoxia was discarded since experiments were carried out under aerobic conditions. Furthermore, as BLEO sensitivity does not increase in the presence of the BLEO hydrolase inhibitor E-64, it can be inferred that the VERO cells did not express significant levels of this inactivating enzyme.

VERO cells have low basal PAR levels, which increase moderately in response to different genotoxic insults. Having tried three different anti-PAR antibodies, we did not detect a sharp increase in PAR levels in response to BLEO. ICF with a $10 \mathrm{H}$ antibody for long-chain PAR showed no basal long-chain PAR and a strong signal in very few BLEO-treated cells was observed. Although it is known that PAR levels can peak and then diminish, the nature of the BLEO treatment implied that at the fixing time, the damage induced at the beginning of the pulse coexisted with the damage induced at the end of the pulse (45 min later). Thus, if VERO cells had been good PAR synthesizers in response to BLEO, we should have detected different degrees of the PARylation signal regardless of its kinetics. PARylation in response to other agents used as positive controls, such as $\mathrm{H}_{2} \mathrm{O}_{2}$ or MMS, was also modest (a very high concentration of the latter, which induced cell death, was necessary to achieve a clear PAR increase). The VERO cells expressed PARP-1/2 and PARG, which were clearly detected by the ICF (Figure 2). Recent evidence shows that a low nuclear PARP-1 level is not the reason why VERO cells are not good PAR synthesizers. According to published Western Blots (WB) results, the level of PARP-1 expression in VERO cells is considerable, with it being similar to that in human epithelial cell lines, such as HEK293 (embryonic kidney), A549 (lung carcinoma) [61], or HEp-2 (laryngeal carcinoma) [62]. In fact, VERO has been chosen as one of the model epithelial cell lines for analyzing the effects of PARP-1 knockdown [61]. The VERO PARP-1 protein sequence (XP 007986456.1) harbors several point amino acid substitutions despite showing a good alignment with hPARP-1 (NP 001609.2). An effect of such mutations in PARP-1 structure and/or activity cannot be formally discarded since several hPARP-1 mutations causing diminished enzymatic activity have been identified [63]

The lack of the potentiation of BLEO-induced damage by OLA was not surprising given the cumulative evidence indicating that OLA can display a range of effects from pro-cell death to protective effects depending on the cellular context $[11,13-24,28,29]$. OLA promotes cell death differentially in cells that have hampered DSB repair (due to a BRCA mutation for example) rather than in cells that have a normal, fully functional, DNA repair systems. As VERO cells do not harbor known mutations in DNA repair genes, this was an expected result. However, the initial DNA damage was measured $(\gamma \mathrm{H} 2 \mathrm{AX}$ positive cells, $\gamma \mathrm{H} 2 \mathrm{AX}$ and 53BP1 foci number, and $\gamma \mathrm{H} 2 \mathrm{AX}$ pan-nuclear cells and DNA damage index) to exclude the possibility that OLA had interfered with the DNA damage induction. It was also confirmed that the $50 \mathrm{nM}$ OLA treatment reached its targets and affected the PARylation. ENZO anti-PAR antibody, which was generated against a 50-unit PAR chain, depicted a measurable and significant PAR increase in the presence of BLEO, which decreased, as expected, under co-treatment with $50 \mathrm{nM}$ OLA (Figure 3). Finally, the WB confirmed that the PARylation increase induced by $\mathrm{H}_{2} \mathrm{O}_{2}$ (detected using MABE1031 anti-PAR reagent) was inhibited by a co-treatment with $50 \mathrm{nM}$ OLA (Figure A4, panel I). An interesting point is that, according to our preliminary data (Figure A4), OLA increased the 53BP1 foci number. These data regarding VERO cells agree with data in HeLa and PtK2 cell lines published by Saquilabon et al. [64], who determined that PARPis induce the increased recruitment of 53BP1 to DNA damage sites. It has been interpreted that PARP-1/2 activation is antagonistic to c-NHEJ, limiting the 53BP1 accumulation at damaged sites [64]. Antagonistic roles 
in the selection of DSB DNA repair pathways have been documented for PARP- 1 vs. Ku $[58,65]$ and BRCA vs. 53BP1 [66,67].

The lack of abundant PAR synthesis in response to DNA damage induction and the absence of potentiation by OLA could be due to the fact that VERO cells were repairing BLEO-induced DNA damage, mainly through PARP-independent pathways. In such a case, blocking these pathways would force cells to become PARP-dependent or die. For this reason, and as an effort to help delineate the boundaries of synthetic lethality, a pool of inhibitors (3i) targeting key enzymes of the two main pathways of DSB repair, namely, HR (ATM inhibitor) and C-NHEJ (DNA-PK and LigIV inhibitor), were used. Cells were exposed to BLEO and a co- and post-treatment with $3 \mathrm{i}$ alone or $3 \mathrm{i}+$ OLA.

The most important point was that since in VERO cells we did inhibit ATM, DNA-PK, and LigIV, and under that condition, a cell subpopulation survived, even in the presence of the PARP inhibitor OLA, no synergism occurred. In fact, our results indicated the presence of a VERO subpopulation that was resistant to BLEO, BLEO + OLA, and BLEO + OLA + ATM inhibitor KU55933 + DNA-PK inhibitor KU-0060648 + LigIV inhibitor SCR7 pyrazine (Figure 5).

An improved understanding of the synthetic lethality strategies will probably extend the use of PARP inhibitors beyond tumors with BRCA1/2 mutations [68]. Aside from drug-drug interactions, known causes for OLA resistance include disturbed PARylation metabolism, alterations in drug transporters, up-regulation of HR, and replication forks [69-71].

As discussed above, although the VERO cells expressed normal PARP levels, poor PARylation was observed and VERO cells harbored PARP mutations of unknown biological meaning. This deserves further study. PARPis resistance has been described in an ovarian cancer patient carrying a point mutation in PARP-1 [70]. Regarding transporters, it is known that P-glycoprotein (P-gP) transporters export OLA, pumping it out of the cell [41]. We have not evaluated whether VERO cells overexpress P-gp transporters. However, PAR diminution in the presence of OLA evidences that OLA is reaching PARP, making P-gp overexpression an unlikely explanation of OLA resistance in VERO cells.

Assuming that all the used inhibitors worked as in other models, one explanation regarding the resistance to BLEO + OLA + $3 \mathrm{i}$ would be that cells repaired DNA damage through a PARP-independent pathway rather than MMEJ (which is PARP-1 dependent) or HR (because ATM was inhibited) or c-NHEJ (since DNA-PK and LigIV were inhibited). Even under the HR defect (due to mutated or inhibited proteins), replication fork stabilization has been proposed as an alternative PARPis resistance mechanism [69,71]. According to Haynes et al. [72], checkpoint kinases ATR, CHK1, and WEE1 play different roles in replication fork stabilization, providing alternative mechanisms to be considered in combination therapy development in order to avoid drug resistance. For example, ATRis (VE-821, VE-822, or AZ20) overcome acquired and pre-existing PARPis resistance in multiple BRCA1-deficient cancer cell lines of distinct origins. Moreover, such cells are preferentially affected over BRCA-proficient or PARP-sensitive cells [73]. ATRi (AZD6738) and WEE1i (AZD1775) display differential activity in a subpopulation of non-germinal-center-B cell (non-GCB) diffuse large B-cell lymphoma (DLBCL) cell lines characterized by high MYC oncogene expression and cyclin-dependent kinase inhibitor 2A/B (CDNK2A/B) deletion [74]. Interestingly, CDKN2A codes alternatively spliced variants that are involved in cell cycle control, including the tumor suppressor p16INK4a. In turn, CHK1 inhibitor Prexasertib is effective against human head and neck squamous cell carcinoma cell lines with CDKN2A genetic losses. Conversely, restoration of p16 expression in hypersensitive cells prevents Prexasertib-induced cell proliferation drop [75].

Does the DDR response and coordination of DNA repair and cell cycling work properly in VERO cells? VERO cells have a homozygous $\approx 9 \mathrm{Mb}$ deletion on chromosome 12 , causing the loss of $\mathrm{CDKN} 2 \mathrm{~A} / \mathrm{B}$ genes, besides the type I interferon gene cluster (which probably explains why they are so infection-prone). Although these mutations by themselves are not enough to transform cells into tumorigenic cells, the loss of CDKN2A/B may play a crucial role in the acquirement of immortality in the VERO cell lineage [49]. Interestingly, CDKN2A gene mutations are found in up to $40 \%$ of familial cases of melanoma, up to $25 \%$ of head and neck squamous cell carcinomas (HNSCC), some breast 
cancers and pancreatic cancers, and others. In some families, CDKN2A gene mutations facilitate the development of only one type of cancer, while in other families, they can lead to a cancer predisposition syndrome, increasing the risk of developing multiple types of cancer. Furthermore, somatic CDKN2A gene mutations have been found in some people with brain tumors and in children with acute lymphoblastic leukemia [76] (From this point of view, VERO cells could be considered a cancer-prone cell model. Furthermore, the effects of mono-treatments and combined treatments with checkpoint kinases inhibitors should be tested. Moreover, further research is needed to know whether CDKN2 mutations are mandatory over mutations regarding its synergism with PARPis. For example, does a BRCA mutated cell lose its synergism with PARPis in general, and with OLA in particular, if it is also mutated in CDKN2A? Could this be an explanation of why some BRCA-mutated breast cancers do not respond to OLA? Efforts to determine the synthetic lethality partners of PARPis [68], ATRis, CHK1is, and WEE1is are being done. Both positive and negative results will be useful for understanding the underlying mechanisms.

\section{Materials and Methods}

\subsection{VERO Cell Culture}

Cercopithecus aethiops (green monkey) VERO cells (ATCC CCL-81, [57]) were cultured in MEM-STA (Capricorn, Capricorn Scientific GmbH, 35085 Ebsdorfergrund, Germany) supplemented with 10\% FBS (Capricorn \# FBS-11A, collected in South America), penicillin/streptomycin (Capricorn PS-B, 100×) and $2 \mathrm{mM} \mathrm{L}$-glutamine at $37^{\circ} \mathrm{C}$ and $5 \% \mathrm{CO}_{2}$. Cells were seeded onto 96 -well cell culture plates for MTT assay, round coverslips in 24-well plates for immunocytofluorescence (ICF), $30 \mathrm{~mm}$ dishes for the comet assay, and $50 \mathrm{~mm}$ dishes for the clonogenic assay.

\subsection{Treatments with BLEO and Inhibitors}

Bleomycin sulfate treatment (BLEO); from NOLVER (Montevideo, Uruguay), NIPPON KAYAKU (Japan), or LKM (Peru) consisted of a 45 min pulse in the absence of FBS. Controls and other experimental conditions were also subjected to $45 \mathrm{~min}$ FBS depletion. Initially, dose-response curves $(0,4,10,20,40$, 80, 160, 200, and $500 \mu \mathrm{g} / \mathrm{mL}$ ) were found. The Olaparib (Tocris, Minneapolis, MN, USA) treatment was continuous. Dose-response curves $(0,50,100,150$, and $200 \mathrm{nM})$ were also found. Then, $40 \mu \mathrm{g} / \mathrm{mL}$ BLEO and 50 nM OLA were selected for the following experiments: OLA effect on the PAR pool was checked and compared with other PARPis and with the PARG inhibitor DEA in untreated VERO cells using ICF with a BD anti-PAR antibody (Figure A3B). While DEA increased PAR, 25 nM OLA did induce an effect that was very similar to $250 \mathrm{nM}$ OLA, diminishing the endogenous PAR by more than $100 \mathrm{nM}$ EB or $5 \mathrm{mM} 3 \mathrm{AB}$. Like with OLA, the treatment with ATM, DNA-PK, and Lig IV inhibitors, namely, $10 \mu \mathrm{M}$ KU55933 (SIGMA SML-1109, St. Louis, Missouri, USA [77]), $0.1 \mu \mathrm{M}$ KU-0060648 (SIGMA SML-1257, St. Louis, MO, USA), and $0.1 \mu \mathrm{M}$ SCR7 Pyrazine (SIGMA SML-1546, St. Louis, MO, USA [78]), was continuous. SIGMA is subsidiary of Merck KGaA (Darmstadt, Germany), and its headquarter is at St. Louis, Missouri, USA.Co-treatments were done with the correspondent inhibitors + BLEO for $45 \mathrm{~min}$; then, for the MTT or clonogenic experiments, BLEO was removed and the inhibitors were added again in a fresh medium with FBS. For the comet assay or ICF, the experiment was stopped and the cells were fixed or lysed immediately after the $45 \mathrm{~min}$ treatment. All times in the graphs refer to the post-BLEO-treatment time. As such, $\mathrm{t}=$ " 0 " means "immediately after the $45 \mathrm{~min}$ BLEO treatment", $\mathrm{t}=24$ is $24 \mathrm{~h}$ later, and so on.

\subsection{Verification of the PARPis and PARGi Effects on VERO Basal PAR Pool}

ICF using an anti-PAR antibody on untreated VERO cells indicated that $25 \mathrm{nM}$ OLA had an effect that was very similar to $250 \mathrm{nM}$ OLA, diminishing the endogenous PAR more than $100 \mathrm{nM}$ EB or 5 mM 3AB. Conversely, the PARG inhibitor DEA induced PAR accumulation. 


\subsection{Cell Viability Assay (MTT)}

Cells were seeded in 96-well plates at a density according to the duration of the experiment (e.g., 15,000/well for $24 \mathrm{~h}$ experiments and 3000/well for $72 \mathrm{~h}$ experiments). The cell viability was determined by a 3-(4,5-dimethylthiazol-2-yl)-2,5-diphenyltetrazolium bromide (MTT) colorimetric assay [79], in which metabolically active cells reduced the dye to purple formazan. Cells were incubated for $1 \mathrm{~h}$ at $37^{\circ} \mathrm{C}$ with MTT $(0.5 \mathrm{mg} / \mathrm{mL}$ final concentration in $10 \mathrm{mM}$ glucose in PBS). Formazan crystals were dissolved with DMSO. The absorbance was measured using a reference wavelength of $630 \mathrm{~nm}$ and a test wavelength of $570 \mathrm{~nm}$ on a Varioskan Flash microplate reader, Thermo Scientific, Waltham, MA, USA).

\subsection{Clonogenic Assay}

Cells were seeded in $50 \mathrm{~mm}$ cell culture dishes at a very low density (1000 cells for treatments and less (500 or 250) for the controls). After the attachment, cell cultures were treated for 45 min with BLEO in the absence or presence of inhibitors. Then, the culture media was changed and fresh inhibitors were added. The cells were incubated until control colonies reached at least 50 cells (counted under the microscope) for 8 days. Finally, colonies were fixed on $70 \%$ ethanol at room temperature (RT) for $10 \mathrm{~min}$, briefly stained with $0.1 \%$ crystal violet (Fluka 61135), rinsed in abundant distilled water, dried at $37^{\circ} \mathrm{C}$, and manually counted by an observer under a magnifying glass. The plates were blind-coded. The clonogenic efficiency was expressed relative to the controls.

\subsection{Comet Assay}

The assay was carried out in alkaline conditions to detect SSB, DSB, and alkali-labile sites [80-82]. The slide's surface was pretreated with $1 \%$ normal melting point agarose (Sigma, St. Louis, MO, USA) in PBS. After a 45 min treatment, the cells were washed with PBS, incubated with trypsin-EDTA for $5 \mathrm{~min}$ at $37^{\circ} \mathrm{C}$, centrifuged, and resuspended in PBS; then, $20 \mu \mathrm{L}$ of cell suspension was mixed with $80 \mu \mathrm{L}$ of $0.75 \%$ low-melting agarose (Sigma, St. Louis, MO, USA) in PBS at $37^{\circ} \mathrm{C}$. Immediately, an $80 \mu \mathrm{L}$ volume of the suspension was placed on a slide, covered with parafilm, and kept at $4{ }^{\circ} \mathrm{C}(10 \mathrm{~min})$. The parafilm was removed and the slide was immersed in a cold lysis buffer $(2.5 \mathrm{M} \mathrm{NaCl}, 100 \mathrm{mM}$ EDTA, $10 \mathrm{mM}$ Tris- $\mathrm{HCl}$, and $8 \mathrm{~g}$ of NaOH/890 $\mathrm{mL}$ of water, adjusted to $\mathrm{pH} 10$, to which was added $1 \%$ Triton-X-100 and 10\% DMSO an hour before use) and kept at $4{ }^{\circ} \mathrm{C}$ (from 1 to 15 days). The slides were incubated in cold electrophoresis buffer $(300 \mathrm{mM} \mathrm{NaOH}$ and $1 \mathrm{mM}$ EDTA at $\mathrm{pH}$ 13) for $20 \mathrm{~min}$ at $4{ }^{\circ} \mathrm{C}$ to unwind the DNA strands and expose the alkali-labile sites. Electrophoresis was performed at $25 \mathrm{~V}$ for $20 \mathrm{~min}$. The buffer volume was adjusted to achieve a current intensity in the range of 250 to $300 \mathrm{~mA}$. After that, the slides were washed with neutralization buffer $(0.4 \mathrm{M}$ Tris-HCl, $\mathrm{pH} 7.5)$ three times for $5 \mathrm{~min}$ each and washed with distilled water. Subsequently, the slides were stained with $80 \mu \mathrm{L}$ of DAPI ( $6 \mu \mathrm{g} / \mathrm{mL})(10 \mathrm{~min})$, washed with distilled water, and covered with coverslips.

Comets were blind-counted under epifluorescence and representative photographs were taken with the confocal microscope in non-confocal conditions (confocal aperture 5) under a $20 \times$ objective and classified according to the degree of damage in five categories: from 1 to 5 ( $\alpha=$ degree of damage). The following criteria were used to assess the degree of damage: 1: no damage and intact or with a halo surrounding the core; 2: a little damage (the DNA was distributed in an oval); 3: the anterior-posterior axis measured twice the diameter; 4 : the compact DNA was reduced and a large cloud of DNA (long tail of the comet) appeared; and 5: the tail was separated from the rest of compact DNA.

A double-blind count of 100 cells was performed. A damage index (DDI) was calculated using the equation: $D D I=\Sigma(n . \alpha)$, where $\alpha$ (which can range from 1 to 5 ) expresses the degree of damage and $n$ is the number of cells with the degree of damage $\alpha$. 


\subsection{Indirect Inmunocytofluorescence and Image Acquisition}

Cells were washed with filtered PBS (fPBS, $0.22 \mu \mathrm{m}$ pore size), fixed in $4 \%$ paraformaldehyde (PFA) in fPBS $15 \mathrm{~min}$ at $4{ }^{\circ} \mathrm{C}$, washed in fPBS, permeabilized in $0.1 \%$ Triton- $\mathrm{X} 100$ in $\mathrm{fPBS}$, and immersed in blocking buffer $(0.2 \%$ Tween, $1 \%$ BSA in fPBS) for $30 \mathrm{~min}$. Briefly, cells were incubated with the specific antibodies, namely, 1:300 rabbit anti-PARP-1/2 (Santa Cruz sc-7150, CA, USA), 1:500 rabbit anti-PAR (BD551813, Becton Dickinson (Franklin Lakes, NJ, USA)), 1:50 mouse anti-PAR (Enzo BML-SA216, Farmingdale, NY, USA), 1:100 10H-anti-PAR (Tulip \#1020), 1:200 anti-hPARG (Abcam 16060, Cambridge, MA, USA), 1:400 mouse monoclonal anti- $\gamma H 2 A X$ (Abcam), and 1:300 anti-53BP1 (Abcam 36828), and diluted in blocking buffer for $2 \mathrm{~h}$ at $37^{\circ} \mathrm{C}$. After washing in fPBS/T ( $0.1 \%$ Tween), cells were incubated $(1 \mathrm{~h}, \mathrm{RT})$ with the correspondent anti-antibodies mix (1:250 anti-mouse-Cy3 Jackson Immuno Research, 1:1000 goat-anti-rabbit 488 (\#A-11034, Thermo Fisher Scientific, Waltham, MA, USA) in a blocking buffer. After washing in fPBS/T and fPBS, DAPI counterstaining $(1.5 \mu \mathrm{g} / \mathrm{mL}$ in fPBS), and a final wash in fPBS, the coverslips were mounted in Prolong Gold (Molecular Probes P36930, Eugene, OR, USA) and sealed with nail polish. Controls without a primary antibody were run in parallel to check the specificity of the signals.

Mainly an Olympus BX61/FV300 (Tokyo, Japan) and sometimes a Zeiss LSM800-Airyscan (Oberkochen, Germany) or a Leica microscope were used to take the confocal images/stacks. Fluorescence excitation was performed with the following lasers: diode $405 \mathrm{~nm}$ (DAPI), multiline argon $488 \mathrm{~nm}$ (Alexa Fluor 488), and helium-neon $561 \mathrm{~nm}$ (Cy3). Microscope settings were adjusted to register no signal in controls without primary antibodies. The scanning of optical sections was performed sequentially for the different fluorochromes. All images in each experimental series were taken with the same setting at the same confocal session. If modified, all were subject to the same degree of brightness/contrast adjustment and Gaussian blur filtering, including the control without a primary antibody. ImageJ free software [83] was used for the image processing.

\subsection{Cell Counting Using Low-Magnification Fields}

The ImageJ "Cell Counter" plug-in [84] (was employed to find out the percentage of nuclei that exhibited no $\gamma \mathrm{H} 2 \mathrm{AX}$, well-defined $\gamma \mathrm{H} 2 \mathrm{AX}$ foci, or $\gamma \mathrm{H} 2 \mathrm{AX}$ pan-nuclear staining.

\subsection{Relative PAR Quantification}

The total field PAR intensity (RawIntDen, the sum of signal intensity in all the image pixels) was normalized using DAPI RawIntDen in each field (to account for putative differences in cell densities). Then, the data were expressed as a percentage of the control.

\subsection{Statistical Analysis}

The results were expressed as mean \pm SEM. Differences between different experimental groups were tested for significance using a two-tailed unequal variances Student's $t$-test in Microsoft Excel 2007 [85] or a one-way analysis of variance (ANOVA), followed by post-hoc multiple comparisons tests (Tukey, Scheffe, Bonferroni, and Holm) in ASTATSA [86])

Author Contributions: Conceptualization, V.P., M.S., P.L., D.J.K., and L.L.-H.; methodology, V.P., M.S., P.L., S.V.-L., and L.L.-H.; formal analysis, V.P., M.S., P.L., S.V.-L., D.J.K., and L.L.-H.; investigation, V.P., M.S., P.L., S.V.-L., D.J.K., and L.L.-H.; resources, V.P., M.S., P.L., S.V.-L., D.J.K., and L.L.-H.; data curation, V.P., M.S., P.L., S.V.-L., D.J.K., and L.L.-H.; writing—original draft preparation, L.L.-H.; writing—review and editing, V.P., M.S., P.L., S.V.-L., D.J.K., and L.L.-H.; visualization, L.L.-H.; supervision, D.J.K; project administration, D.J.K.; funding acquisition, V.P., M.S., D.J.K., and L.L.-H. All authors have read and agreed to the published version of the manuscript (CRediT taxonomy).

Funding: This research was partially funded by an undergraduate Student Research Support Program, call 2017: "Programa de Apoyo a la Investigación Estudiantil, Comisión Sectorial de Investigación Científica" (PAIE-CSIC UdelaR, Uruguay). Project title: Poly(ADP-ribosylation) and VERO cells' response to induced DNA damage. Responsible student: V.P.; responsible professor: D.J.K; co-responsible: L.L.H. Some reagents were bought through 
Programa de Desarrollo de las Ciencias Básicas (PEDECIBA). APC contributors: PEDECIBA BIOLOGIA (aliquots given to researchers D.J.K., L.L.-H and R. Daniel Peluffo, CENUR); and Ministerio de Educación y Cultura.

Acknowledgments: Agencia Nacional de Investigación e Innovación (ANII-SNI). Bleomycin sulfate (Bleocris 15, LKM) was a gift from Laboratorios Teva Uruguay S.A., Grupo Biotoscana. The single-cell electrophoresis chamber and power supply were from the Epigenetics and Genomic Instability Lab, Instituto de Investigaciones Biológicas Clemente Estable (IIBCE). The alternative $\mathrm{CO}_{2}$ incubators used came from the Neurochemistry Department, IIBCE, and the Microbiology Department, IIBCE. Part of the VERO cell stock was kept at Facultad de Ciencias, UdelaR. G. A. Folle kindly contributed to the text editing. Thanks to R.D. Peluffo and to Ministerio de Educación y Cultura, Dirección para el Desarrollo de la Ciencia y el Conocimimento, for financial contributions to pay APC.

Conflicts of Interest: The authors declare no conflict of interest. The funders had no role in the design of the study; in the collection, analyses, or interpretation of data; in the writing of the manuscript, or in the decision to publish the results.

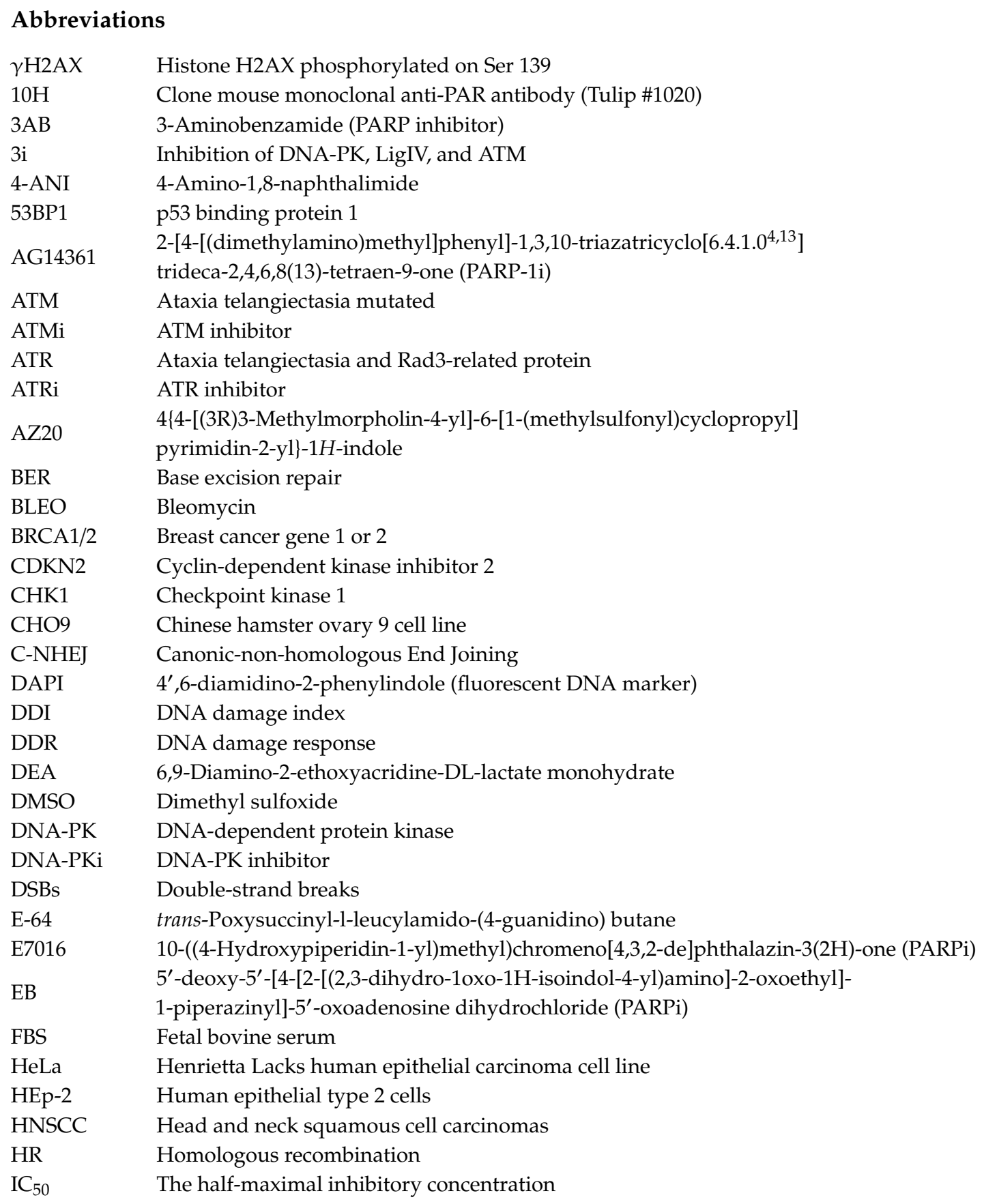


ICF Inmunocytofluorescence

INO1001 3-Aminobenzamide (PARP inhibitor)

IR Ionizing radiation

KU-0060648 4-Ethyl-N-[4-[2-(4-morpholinyl)-4-oxo-4H-1-benzopyran-8-yl]-

KU55933 2-Morpholin-4-yl-6-thianthren-1-yl-pyran-4-one

KU70/80 Ku heterodimer: Ku70 (XRCC6) and Ku80 (XRCC5)

LigIII DNA ligase 3

LigIV DNA ligase 4

LigIVi LigIV inhibitor

MAPK Mitogen-activated protein kinase

MEM Minimum essential medium

MMEJ Microhomology-mediated end joining

MMS Methylmethanosulfonate

MRE11 Complex consisting of meiotic recombination 11

Mst-1 Macrophage-stimulating 1 (mitogen-activated protein kinase)

MTT 3-(4,5-dimethylthiazol-2-yl)-2,5-diphenyltetrazolium bromide

NAD+ Nicotinamide adenine dinucleotide

Nam Nicotinamide

NMuMG Nontransformed mouse mammary gland epithelial cell line

OLA Name:4-[[3-[4-(cyclopropanecarbonyl)piperazine-1-carbonyl]4-fluorophenyl]methyl]-2H-phthalazin-1-one

p38 A class of MAPK

PAR Poly(ADP-ribose)

PARG Poly-ADP-glicohidrolase

PARP Poly(ADP-ribosyl) polymerase

PARPis PARP inhibitors

PARylation Poly(ADP-ribosylation)

PBS Phosphate-buffered saline

PFA Paraformaldehyde

Pol $\beta \quad$ DNA polymerase $\beta$

$\begin{array}{ll}\text { Prexacertib } & \text { 5-[[5-[2-(3-aminopropoxy)-6-methoxyphenyl]- } \\ & \text { 1H-pyrazol-3-yl]amino]pyrazine-2-carbonitrile (CHK1 inhibitor) }\end{array}$

PtK2 Male rat kangaroo kidney epithelial cell

RT Room temperature

SSBs Single-strand breaks

TNKS Tankyrase

UV-C Ultraviolet $C$ radiation

VE-821 3-amino-6-(4-methylsulfonylphenyl)-N-phenylpyrazine-2-carboxamide (ATRi)

VE-822 3-[3-[4-(methylaminomethyl)phenyl]-1,2-oxazol-5-yl]-

VERO 5-(4-propan-2-ylsulfonylphenyl)pyrazin-2-amine

VRK1 Vaccinia-related kinase 1

WBWEE1 Western BlotsG2 checkpoint kinase

XRCC1 X-ray repair cross-complementing protein 1 


\section{Appendix A}

A Cell viability: dose-response to BLEO

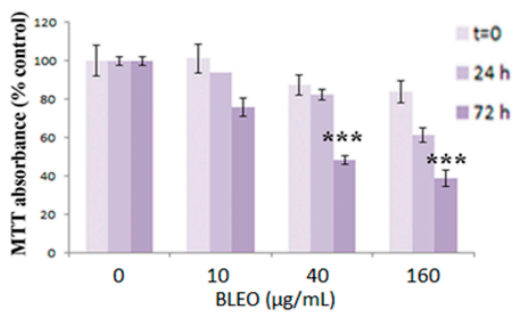

C Cell viability in the presence of E-64

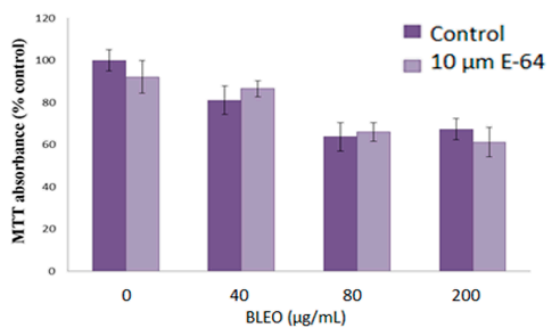

B Cell viability : higher BLEO doses

or longer pulse duration

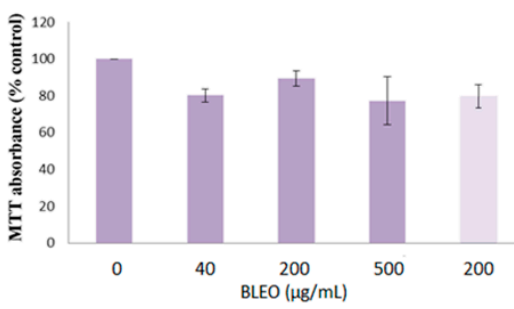

D Cell viability in the presence of OLA

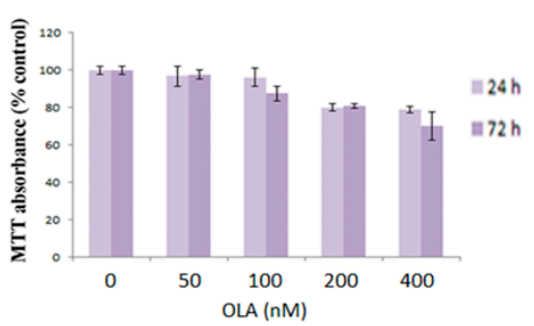

Figure A1. BLEO and OLA curves. Cell viability (MTT assay). (A) Cells were exposed to BLEO in the indicated doses $(0-160 \mu \mathrm{g} / \mathrm{mL})$ during a $45 \mathrm{~min}$ pulse. Then, cells were cultured during the indicated time before the MTT addition $(0,24$, or $72 \mathrm{~h}$, where " $\mathrm{t}=0$ " refers to immediately after the treatment). The 2018-2020 dataset includes 20 MTT experiments with BLEO in VERO cells. At 72 h, $n=63,6$, 72 , and 22 for increasing BLEO concentrations. Fewer data were recorded for shorter times and are depicted to facilitate understanding of the chosen schedule. ${ }^{* * *}: p<0.001$. (B) Cell viability (24 h) under higher BLEO doses or longer BLEO pulse durations. Cells were exposed to BLEO in the indicated doses $(0-500 \mu \mathrm{g} / \mathrm{mL})$ during a $45 \mathrm{~min}$ pulse or (last bar) during $270 \mathrm{~min}$. (C) Cell viability (24 h) in the control and BLEO-exposed cells in the absence or presence of a co-treatment (45 min pulse) with bleomycin hydrolase inhibitor E64. (D) Cell viability after exposure to OLA (0-400 nM). The whole curve was done once at $24 \mathrm{~h}$ and once at $72 \mathrm{~h}$. In contrast, for $50 \mathrm{nM}$ Olaparib at $72 \mathrm{~h}, n=75$ from 12 independent experiments.

\section{Appendix B}

A

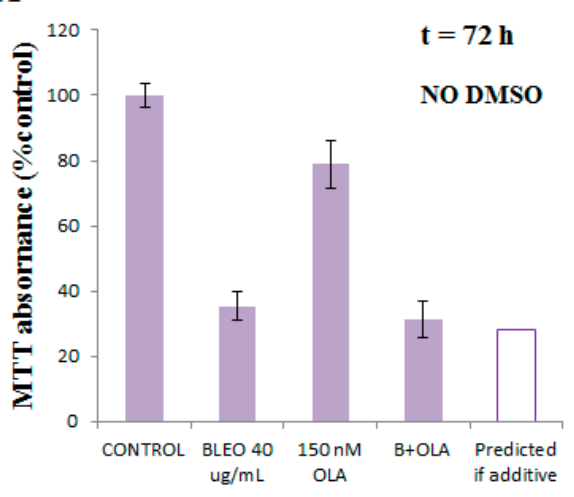

B

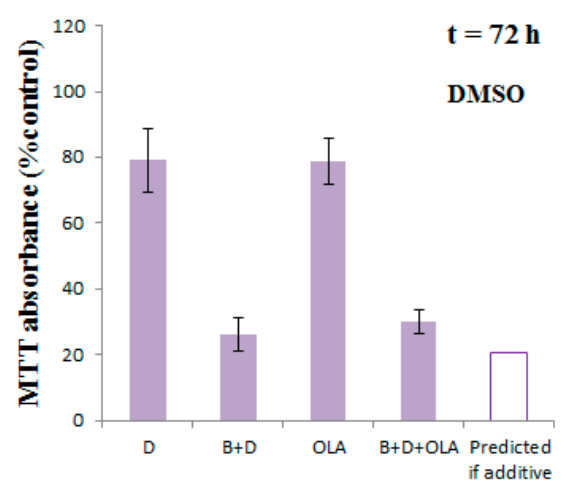

Figure A2. Concentrations of $150 \mathrm{nM}$ OLA and BLEO. A single experiment was carried out to explore whether an increase in OLA concentration would lead to potentiation. Effect of combined $150 \mathrm{nM}$ OLA and $40 \mu \mathrm{g} / \mathrm{mL}$ BLEO in the absence (A) or presence (B) of DMSO on VERO cell viability was evaluated using MTT $(72 \mathrm{~h})$. Mean \pm SD. $n=6$. Since the predicted additive effect according to Webb's equation [25] was equal or lower than the combined effect, synergism was discarded. 


\section{Appendix C}

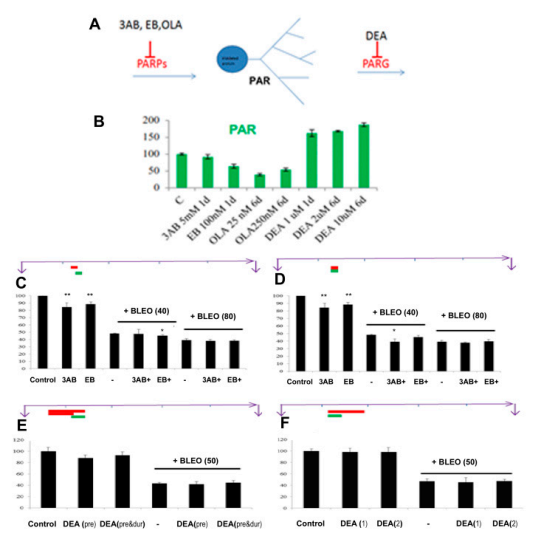

Figure A3. PARPis and BLEO in VERO. PARPis and BLEO in VERO. (A) Scheme representing PAR, its synthesis by PARPs, its degradation mainly by poly-ADP-glycohydrolase (PARG) activity, and the inhibitors abbreviations associated with the correspondent enzyme. $3 \mathrm{AB}, \mathrm{EB}$, and OLA are PARPis, while DEA inhibits PARG. (B) Test of the inhibitors' effects on PAR. The inhibitors used were 3-aminobenzamide (3AB, Sigma A-0788), 5' -deoxy-5' -[4-[2-[(2,3-dihydro-1oxo-1H-isoindol-4-yl)amino]2-oxoethyl]-1-piperazinyl]-5'-oxoadenosine dihydrochloride (EB, Alexis Biochemicals), 6,9-diamino2-ethoxyacridine-DL-lactate monohydrate (DEA, Trevigen 4680-096-03), and OLA. PAR was measured on confocal planes of monolayers using the Analyze/Measure ImageJ plugin, and the results are expressed as arbitrary fluorescence units/area. (C-F) Cell viability assays. Results are expressed as \% MTT absorbance with respect to control. The violet arrows at the top of each graph represent the time in days ( 5 days) from seeding to MTT evaluation. The bleomycin treatment ( 40 to $80 \mu \mathrm{g} / \mathrm{mL}, 45 \mathrm{~min}$ ) is represented in green and the inhibitors' treatment durations are in red. $(C)$ Pre-treatment with $3 \mathrm{AB}$ or EB, (D) co-treatment with $3 \mathrm{AB}$ or EB, (E) pre- and co-treatment with the PARG inhibitor DEA, and $(\mathrm{F})$ co- and post-treatment with DEA. The genotoxic treatment was always different from the control $(p<0.001)$. Asterisks refer to a comparison of a treatment vs. the control or with respect to the genotoxic treatment. *: $p<0.05,{ }^{* *}: p<0.01$.

\section{Appendix D}

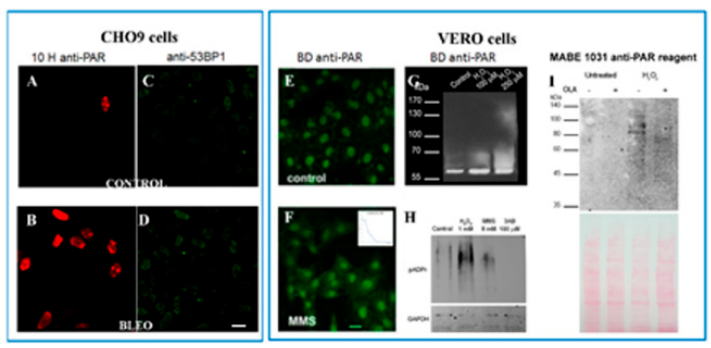

Figure A4. Positive controls for anti-PAR antibodies. (A-D) Comparison of the control (A,C) and BLEO-treated cells (B,D; $40 \mu \mathrm{g} / \mathrm{mL}, 45 \mathrm{~min}$, like VERO) that were indirectly immunostained with $10 \mathrm{H}$ anti-PAR (A,B, red) and anti-53BP1 (C,D, green) Bar: $15 \mu \mathrm{m}$. PAR-positive nuclei were much more frequent in $\mathrm{CHO} 9$ than in VERO cells. (E,F) ICF with BD anti-PAR antibody (same experiment as in Figure 3G,H, extracted from Ph.D. thesis [53] Bar: $25 \mu \mathrm{m}$ ). Only after a very strong treatment with MMS (F; $6 \mathrm{mM}, 45 \mathrm{~min}$ ), which induced cell death of the whole cell population (insert), was a slight PAR increase noticed with BD anti-PAR. (G) WB detecting PAR with BD anti-PAR in control cells or cells exposed to 100 and $250 \mu \mathrm{M} \mathrm{H}_{2} \mathrm{O}_{2}$. (H) WB detecting PAR indirectly with the rabbit PAR-binding reagent MABE1031 (1:4000) and anti-rabbit-HRP in control VERO cells or under exposure to $1 \mathrm{mM}$ $\mathrm{H}_{2} \mathrm{O}_{2}$ (10 min), $8 \mathrm{mM}$ MMS (45 min), or the PARP inhibitor 3AB (2 h). (I) WB detecting PAR with MABE1031 in the control VERO cells or under exposure to OLA $(1 \mathrm{~h}), \mathrm{H}_{2} \mathrm{O}_{2}$ (last $10 \mathrm{~min}$ ), or the combined treatment OLA $+\mathrm{H}_{2} \mathrm{O}_{2}$. 


\section{Appendix E}

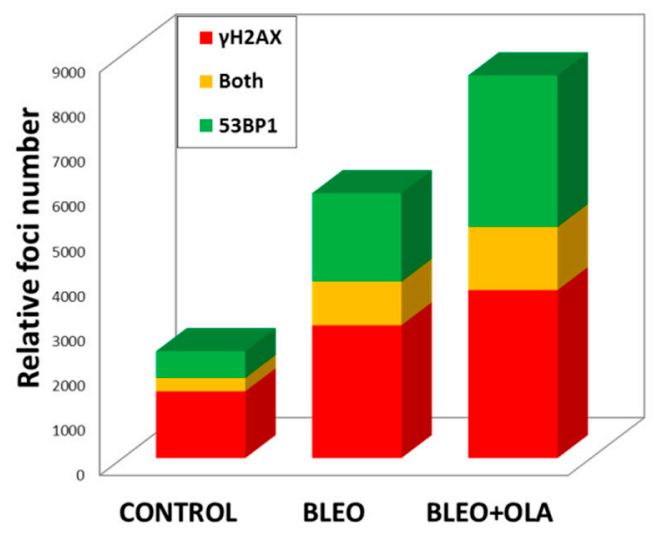

Figure A5. $\gamma \mathrm{H} 2 \mathrm{AX}$ vs. $53 \mathrm{BP} 1$ foci distribution in one experiment. Foci counting required the following steps, which were done in batch: (1) Separate channels. (2) Segment images to obtain a mask using a fixed threshold for all images of the experiment in each channel. In this case, the following thresholds were used: 50 for the red channel $(\gamma \mathrm{H} 2 \mathrm{AX}), 62$ for the green channel (53BP1), and 40 for the blue (DAPI) channel. (3) The Analyze Particles plug-in allowed for counting objects with certain properties, namely, circularity and size. Foci were defined as ovoid to circular objects (circularity >0.5) and 5 to 200 pixels. Nuclei were defined as ovoid objects measuring 500 to 500,000 pixels. In each case, the program showed the masks, displayed results, and summarized the data. In this way, we obtained the number of $\gamma \mathrm{H} 2 \mathrm{AX}$ foci, $52 \mathrm{BP} 1 \mathrm{foci}$, and cell number. (4) In order to determine the number of mixed foci (positive both for $\gamma \mathrm{H} 2 \mathrm{AX}$ and $53 \mathrm{BP} 1$ ), mask images (which are 0 or 1 matrixes) were multiplied. In this way, a signal remained in pixels positive for $\gamma \mathrm{H} 2 \mathrm{AX}$ and 53BP1 $(1 \times 1=1)$ while no signal was obtained in a pixel if at least one of the channels was black $(1 \times 0=0)$. After that, we had objects representing partial foci superimposition. In order to avoid artifacts or overcounting, we used the Analyze Particles Plugin again to count only whole foci. Again, foci were defined as ovoid to circular objects (circularity > 0.5) measuring 5 to 200 pixels. (5) Mixed foci were subtracted from the total $\gamma \mathrm{H} 2 \mathrm{AX}$ foci and from the total 53BP1 foci to obtain the numbers of foci with only one mark. (6) $\gamma \mathrm{H} 2 \mathrm{AX}$ alone, 53BP1 alone, and mixed foci numbers were normalized by cell number. Data were from a single experiment using 10 microscopic fields (40× zoom 2) per condition. Foci counting involved 247 control cells, 176 BLEO cells, and 119 (BLEO + OLA) cells.

\section{References}

1. Teloni, F.; Altmeyer, M. Survey and summary readers of poly(ADP-ribose): Designed to be fit for purpose. Nucleic Acids Res. 2016, 44, 993-1006. [CrossRef] [PubMed]

2. Althaus, F.R.; Kleczkowska, H.E.; Malanga, M.; Müntener, C.R.; Pleschke, J.M.; Ebner, M.; Auer, B. Poly ADP-ribosylation: A DNA break signal mechanism. Proc. Mol. Cell. Biochem. 1999, 193, 5-11. [CrossRef]

3. Gagné, J.P.; Pic, É.; Isabelle, M.; Krietsch, J.; Éthier, C.; Paquet, É.; Kelly, I.; Boutin, M.; Moon, K.M.; Foster, L.J.; et al. Quantitative proteomics profiling of the poly(ADP-ribose)-related response to genotoxic stress. Nucleic Acids Res. 2012, 40, 7788-7805. [CrossRef] [PubMed]

4. Blackford, A.N.; Jackson, S.P. ATM, ATR, and DNA-PK: The Trinity at the Heart of the DNA Damage Response. Mol. Cell 2017, 66, 801-817. [CrossRef]

5. Salzano, M.; Sanz-García, M.; Monsalve, D.M.; Moura, D.S.; Lazo, P.A. VRK1 chromatin kinase phosphorylates $\mathrm{H} 2 \mathrm{AX}$ and is required for foci formation induced by DNA damage. Epigenetics 2015, 10, 373-383. [CrossRef]

6. Maréchal, A.; Zou, L. DNA damage sensing by the ATM and ATR kinases. Cold Spring Harb. Perspect. Biol. 2013, 5, a012716. [CrossRef]

7. Dueva, R.; Iliakis, G. Alternative pathways of non-homologous end joining (NHEJ) in genomic instability and cancer. Transl. Cancer Res. 2013, 2, 163-177. [CrossRef] 
8. Mladenov, E.; Iliakis, G. The Pathways of Double-Strand Break Repair. In DNA Repair-On the Pathways to Fixing DNA Damage and Errors; Storici, F., Ed.; InTech: London, UK, 2011; pp. 143-168. ISBN 978-953-307-649-2.

9. Ray Chaudhuri, A.; Nussenzweig, A. The multifaceted roles of PARP1 in DNA repair and chromatin remodelling. Nat. Rev. Mol. Cell Biol. 2017, 18, 610-621. [CrossRef] [PubMed]

10. Hottiger, M.O. SnapShot: ADP-Ribosylation Signaling. Mol. Cell 2015, 58, 1134-1134.e1. [CrossRef]

11. Virag, L.; Szabo, C. The Therapeutic Potential of Poly(ADP-Ribose) Polymerase Inhibitors. J. Natl. Cancer Inst. 2011, 103, 334-346. [CrossRef]

12. Kraus, W.L. PARPs and ADP-Ribosylation: 50 Years ... and Counting. Mol. Cell 2015, 58, 902-910. [CrossRef]

13. Thraves, P.; Mossman, K.L.; Brennan, T.; Dritschilo, A. Radiosensitization of human fibroblasts by 3-aminobenzamide: An inhibitor of poly(ADP-ribosylation). Radiat. Res. 1985, 104, 119-127. [CrossRef]

14. Brock, W.A.; Milas, L.; Bergh, S.; Lo, R.; Szabo, C.; Mason, K.A. Radiosensitization of human and rodent cell lines by INO-1001, a novel inhibitor of poly(ADP-ribose) polymerase. Cancer Lett. 2004, 205, 155-160. [CrossRef]

15. Arundel-Suto, C.M.; Scavone, S.V.; Turner, W.R.; Suto, M.J.; Sebolt-Leopold, J.S. Effect of PD 128763, a new potent inhibitor of poly(ADP-ribose) polymerase, on X-ray-induced cellular recovery processes in Chinese hamster V79 cells. Radiat. Res. 1991, 126, 367-371. [CrossRef]

16. Oleinick, N.L.; Evans, H.H. Poly(ADP-ribose) and the response of cells to ionizing radiation. Radiat. Res. 1985, 101, 29-46. [CrossRef]

17. Russo, A.L.; Kwon, H.-C.; Burgan, W.E.; Carter, D.; Beam, K.; Weizheng, X.; Zhang, J.; Slusher, B.S.; Chakravarti, A.; Tofilon, P.J.; et al. In vitro and In vivo Radiosensitization of Glioblastoma Cells by the Poly (ADP-Ribose) Polymerase Inhibitor E7016. Clin. Cancer Res. 2009, 15, 607-612. [CrossRef]

18. Veuger, S.J.; Curtin, N.J.; Richardson, C.J.; Smith, G.C.M.; Durkacz, B.W. Radiosensitization and DNA repair inhibition by the combined use of novel inhibitors of DNA-dependent protein kinase and poly(ADP-ribose) polymerase-1. Cancer Res. 2003, 63, 6008-6015.

19. Noel, G.; Godon, C.; Fernet, M.; Giocanti, N.; Megnin-Chanet, F.; Favaudon, V. Radiosensitization by the poly(ADP-ribose) polymerase inhibitor 4-amino-1,8-naphthalimide is specific of the $\mathrm{S}$ phase of the cell cycle and involves arrest of DNA synthesis. Mol. Cancer Ther. 2006, 5, 564-574. [CrossRef] [PubMed]

20. Huet, J.; Laval, F. Potentiation of Cell Killing by Inhibitors of Poly (Adenosine Diphosphate-Ribose) Synthesis in Bleomycin-treated Chinese Hamster Ovary Cells. Cancer Res. 1985, 45, 987-991.

21. Kelland, L.R.; Burgess, L.; Steel, G.G. Radiation damage repair capacity of a human germ-cell tumour cell line: Inhibition by 3-aminobenzamide. Int. J. Radiat. Biol. Relat. Stud. Phys. Chem. Med. 1987, 51, 227-241. [CrossRef]

22. Horton, J.K.; Stefanick, D.F.; Naron, J.M.; Kedar, P.S.; Wilson, S.H. Poly(ADP-ribose) polymerase activity prevents signaling pathways for cell cycle arrest after DNA methylating agent exposure. J. Biol. Chem. 2005, 280, 15773-15785. [CrossRef]

23. Cleaver, J.E.; Bodello, W.J.; Morgan, W.F.; Zellell, B. Poly (ADP-ribose) of Repair of DNA Differences in the Regulation by and Ultraviolet Light According to Damage from Alkylating Agents Cell Type. J. Biol. Chem. 1983, 258, 9059-9068.

24. Vodenicharov, M.D.; Ghodgaonkar, M.M.; Halappanavar, S.S.; Shah, R.G.; Shah, G.M. Mechanism of early biphasic activation of poly(ADP-ribose) polymerase-1 in response to ultraviolet B radiation. J. Cell Sci. 2005, 118, 589-599. [CrossRef]

25. Chou, T.-C. Theoretical basis, experimental design, and computerized simulation of synergism and antagonism in drug combination studies. Pharmacol. Rev. 2006, 58, 621-681. [CrossRef] [PubMed]

26. Saha, T.; Smulson, M.; Rosen, E.M. BRCA1 regulation of base excision repair pathway. Cell Cycle 2010, 9, 2471-2472. [CrossRef]

27. Helleday, T. The underlying mechanism for the PARP and BRCA synthetic lethality: Clearing up the misunderstandings. Mol. Oncol. 2011, 5, 387-393. [CrossRef]

28. Ström, C.E.; Johansson, F.; Uhlén, M.; Szigyarto, C.A.K.; Erixon, K.; Helleday, T. Poly (ADP-ribose) polymerase (PARP) is not involved in base excision repair but PARP inhibition traps a single-strand intermediate. Nucleic Acids Res. 2011, 39, 3166-3175. [CrossRef]

29. Horton, J.K.; Stefanick, D.F.; Prasad, R.; Gassman, N.R.; Kedar, P.S.; Wilson, S.H. Base excision repair defects invoke hypersensitivity to PARP inhibition. Mol. Cancer Res. 2014, 12, 1128-1139. [CrossRef] 
30. Czyż, M.; Toma, M.; Gajos-Michniewicz, A.; Majchrzak, K.; Hoser, G.; Szemraj, J.; Nieborowska-Skorska, M.; Cheng, P.; Gritsyuk, D.; Levesque, M.; et al. PARP1 inhibitor olaparib (Lynparza) exerts synthetic lethal effect against ligase 4-deficient melanomas. Oncotarget 2016, 7, 75551-75560. [CrossRef]

31. Ko, H.L.; Ren, E.C. Functional aspects of PARP1 in DNA repair and transcription. Biomolecules 2012, 2, 524-548. [CrossRef]

32. Feng, F.Y.; de Bono, J.S.; Rubin, M.A.; Knudsen, K.E. Chromatin to Clinic: The Molecular Rationale for PARP1 Inhibitor Function. Mol. Cell 2015, 58, 925-934. [CrossRef] [PubMed]

33. Bai, P. Review Biology of Poly (ADP-Ribose) Polymerases: The Factotums of Cell Maintenance. Mol. Cell 2015, 58, 947-958. [CrossRef]

34. Berger, N.A.; Besson, V.C.; Boulares, A.H.; Bürkle, A.; Chiarugi, A.; Clark, R.S.; Curtin, N.J.; Cuzzocrea, S.; Dawson, T.M.; Dawson, V.L.; et al. Opportunities for the repurposing of PARP inhibitors for the therapy of non-oncological diseases. Br. J. Pharmacol. 2018, 175, 192-222. [CrossRef]

35. Sleijfer, S. Bleomycin-induced pneumonitis. Chest 2001, 120, 617-624. [CrossRef]

36. Beck, C.; Robert, I.; Reina-San-Martin, B.; Schreiber, V.; Dantzer, F. Poly(ADP-ribose) polymerases in double-strand break repair: Focus on PARP1, PARP2 and PARP3. Exp. Cell Res. 2014, 329, 18-25. [CrossRef]

37. Sukhanova, M.V.; Abrakhi, S.; Joshi, V.; Pastre, D.; Kutuzov, M.M.; Anarbaev, R.O.; Curmi, P.A.; Hamon, L.; Lavrik, O.I. Single molecule detection of PARP1 and PARP2 interaction with DNA strand breaks and their poly(ADP-ribosyl)ation using high-resolution AFM imaging. Nucleic Acids Res. 2015. [CrossRef]

38. Fouquin, A.; Guirouilh-Barbat, J.; Lopez, B.; Hall, J.; Amor-Guéret, M.; Pennaneach, V. PARP2 controls double-strand break repair pathway choice by limiting 53BP1 accumulation at DNA damage sites and promoting end-resection. Nucleic Acids Res. 2017, 45, 12325-12339. [CrossRef]

39. Rulten, S.L.; Fisher, A.E.O.; Robert, I.; Zuma, M.C.; Rouleau, M.; Ju, L.; Poirier, G.; Reina-San-Martin, B.; Caldecott, K.W. PARP-3 and APLF function together to accelerate nonhomologous end-joining. Mol. Cell 2011, 41, 33-45. [CrossRef] [PubMed]

40. Grundy, G.J.; Polo, L.M.; Zeng, Z.; Rulten, S.L.; Hoch, N.C.; Paomephan, P.; Xu, Y.; Sweet, S.M.; Thorne, A.W.; Oliver, A.W.; et al. PARP3 is a sensor of nicked nucleosomes and monoribosylates histone H2B Glu2. Nat. Commun. 2016, 7. [CrossRef] [PubMed]

41. Oplustil O'Connor, L.; Rulten, S.L.; Cranston, A.N.; Odedra, R.; Brown, H.; Jaspers, J.E.; Jones, L.; Knights, C.; Evers, B.; Ting, A.; et al. The PARP Inhibitor AZD2461 Provides Insights into the Role of PARP3 Inhibition for Both Synthetic Lethality and Tolerability with Chemotherapy in Preclinical Models. Cancer Res. 2016, 76, 6084-6094. [CrossRef]

42. Nagy, Z.; Kalousi, A.; Furst, A.; Koch, M.; Fischer, B.; Soutoglou, E. Tankyrases Promote Homologous Recombination and Check Point Activation in Response to DSBs. PLoS Genet. 2016, 12, 1-26. [CrossRef]

43. Vilchez Larrea, S.C.; Haikarainen, T.; Narwal, M.; Schlesinger, M.; Venkannagari, H.; Flawiá, M.M.; Villamil, S.H.F.; Lehtiö, L. Inhibition of poly(ADP-ribose) Polymerase Interferes with Trypanosoma cruzi Infection and Proliferation of the Parasite. PLoS ONE 2012, 7, e46063. [CrossRef]

44. Thorsell, A.G.; Ekblad, T.; Karlberg, T.; Löw, M.; Pinto, A.F.; Trésaugues, L.; Moche, M.; Cohen, M.S.; Schüler, H. Structural Basis for Potency and Promiscuity in Poly(ADP-ribose) Polymerase (PARP) and Tankyrase Inhibitors. J. Med. Chem. 2017, 60, 1262-1271. [CrossRef]

45. Sharif-Askari, B.; Amrein, L.; Aloyz, R.; Panasci, L. PARP3 inhibitors ME0328 and olaparib potentiate vinorelbine sensitization in breast cancer cell lines. Breast Cancer Res. Treat. 2018, 172, 23-32. [CrossRef]

46. Murai, J.; Huang, S.Y.N.; Das, B.B.; Renaud, A.; Zhang, Y.; Doroshow, J.H.; Ji, J.; Takeda, S.; Pommier, Y. Trapping of PARP1 and PARP2 by clinical PARP inhibitors. Cancer Res. 2012, 72, 5588-5599. [CrossRef]

47. Terasima, T.; Takabe, Y.; Katsumata, T.; Watanabe, M.; Umezawa, H. Effect of Bleomycin on Mammalian Cell Survival. J. Natl. Cancer Inst. 1972, 49, 1093-1100.

48. Sheets, R. History and Characterization of the Vero Cell Line. Open Sess. 2000, 1-12.

49. Naoki, O.; Arihiro, K.; Toshiyuki, Y.; Noriko, H.; Fumio, K.; Suyoshi, S.; Makoto, K.; Kentaro, H.; Hattori, M. The genome landscape of the African Green Monkey kidney-derived vero cell line. DNA Res. 2014, 21, 673-683. [CrossRef]

50. Ammerman, A. NIH Public Access. Curr. Protoc. Microbiol. 2009, 1-10. [CrossRef]

51. Duran-Rehbein, G.A.; Vargas-Zambrano, J.C.; Cuéllar, A.; Puerta, C.J.; Gonzalez, J.M. Mammalian cellular culture models of trypanosoma cruzi infection: A review of the published literature. Parasite 2014, 21. [CrossRef] 
52. Schacke, M.; Kumar, J.; Colwell, N.; Hermanson, K.; Folle, G.A.; Nechaev, S.; Dhasarathy, A.; Lafon-Hughes, L. PARP-1/2 inhibitor olaparib prevents or partially reverts EMT induced by TGF- $\beta$ in NMuMG cells. Int. J. Mol. Sci. 2019, 20, 518. [CrossRef]

53. Kawamitsu, H.; Hoshino, H.; Okada, H.; Miwa, M.; Momoi, H.; Sugimura, T. Monoclonal antibodies against poly(ADP-ribose) recognize different structures of poly(ADP-ribose). Biochemistry 1984, 23, 41-47. [CrossRef]

54. Gagné, J.P.; Isabelle, M.; Lo, K.S.; Bourassa, S.; Hendzel, M.J.; Dawson, V.L.; Dawson, T.M.; Poirier, G.G. Proteome-wide identification of poly(ADP-ribose) binding proteins and poly(ADP-ribose)-associated protein complexes. Nucleic Acids Res. 2008, 36, 6959-6976. [CrossRef]

55. Fahrer, J.; Kranaster, R.; Altmeyer, M.; Marx, A.; Bürkle, A. Quantitative analysis of the binding affinity of poly(ADP-ribose) to specific binding proteins as a function of chain length. Nucleic Acids Res. 2007, 35. [CrossRef] [PubMed]

56. Lafon-Hughes, L. Localización Preferencial del Daño Genético en Regiones Eucromáticas y Replicantes de los Cromosomas y los Núcleos de Mamíferos. Roles de la Poli-ADP-Ribosa en Presencia y Ausencia de Daño Genético Inducido en Células VERO. Ph.D. Thesis, Facultad de Ciencias_PEDECIBA, IIBCE, INGEBI, Universidad de la República, Montevideo, Uruguay, 2014. Available online: http://www.bib.fcien.edu.uy/ files/etd/biol/uy24-17142.pdf (accessed on 3 November 2020).

57. Lafon-Hughes, L.; Vilchez Larrea, S.C.; Kun, A.; Fernández Villamil, S.H. VERO cells harbor a poly-ADP-ribose belt partnering their epithelial adhesion belt. PeerJ 2014, 2, e617. [CrossRef] [PubMed]

58. Wang, M.; Wu, W.; Wu, W.; Rosidi, B.; Zhang, L.; Wang, H.; Iliakis, G. PARP-1 and Ku compete for repair of DNA double strand breaks by distinct NHEJ pathways. Nucleic Acids Res. 2006, 34, 6170-6182. [CrossRef] [PubMed]

59. Burger, R.M. Cleavage of nucleic acids by bleomycin. Chem. Rev. 1998, 98, 1153-1169. [CrossRef]

60. Lafon-Hughes, L.; Di Tomaso, M.V.; Liddle, P.; Toledo, A.; Reyes-Ábalos, A.L.; Folle, G.A. Preferential localization of $\gamma \mathrm{h} 2 \mathrm{AX}$ foci in euchromatin of retina rod cells after DNA damage induction. Chromosome Res. 2013, 21. [CrossRef]

61. Xia, C.; Wolf, J.J.; Sun, C.; Xu, M.; Studstill, C.J.; Chen, J.; Ngo, H.; Zhu, H.; Hahm, B. PARP1 Enhances Influenza A Virus Propagation by Facilitating Degradation of Host Type I Interferon Receptor. J. Virol. 2020, 94, e01572-19. [CrossRef]

62. Nguyen, M.L.; Kraft, R.M.; Blaho, J.A. African green monkey kidney Vero cells require de novo protein synthesis for efficient herpes simplex virus 1-dependent apoptosis. Virology 2005, 336, 274-290. [CrossRef]

63. The UniProt Consortium UniProt: A worldwide hub of protein knowledge. Nucleic Acids Res. 2019, 47, D506-D515. [CrossRef]

64. Cruz, G.M.S.; Kong, X.; Silva, B.A.; Khatibzadeh, N.; Thai, R.; Berns, M.W.; Yokomori, K. Femtosecond near-infrared laser microirradiation reveals a crucial role for PARP signaling on factor assemblies at DNA damage sites. Nucleic Acids Res. 2015, 44,1-17. [CrossRef]

65. Hochegger, H.; Dejsuphong, D.; Fukushima, T.; Morrison, C.; Sonoda, E.; Schreiber, V.; Zhao, G.Y.; Saberi, A.; Masutani, M.; Adachi, N.; et al. Parp-1 protects homologous recombination from interference by Ku and Ligase IV in vertebrate cells. EMBO J. 2006, 25, 1305-1314. [CrossRef]

66. Scully, R.; Xie, A. Double strand break repair functions of histone H2AX. Mutat. Res.-Fundam. Mol. Mech. Mutagen. 2013, 750, 5-14. [CrossRef]

67. Orr, K.S.; Savage, K.I. The BRCA1 and BRCA2 Breast and Ovarian Cancer Susceptibility Genes-Implications for DNA Damage Response, DNA Repair and Cancer Therapy. In Advances in DNA Repair; InTech: London, UK, 2015.

68. Kawahara, N.; Ogawa, K.; Nagayasu, M.; Kimura, M.; Sasaki, Y.; Kobayashi, H. Candidate synthetic lethality partners to parp inhibitors in the treatment of ovarian clear cell cancer (Review). Biomed. Rep. 2017, 7, 391-399. [CrossRef] [PubMed]

69. D'Andrea, A.D. Mechanisms of PARP inhibitor sensitivity and resistance. DNA Repair 2018, 71, $172-176$. [CrossRef]

70. Pettitt, S.J.; Krastev, D.B.; Brandsma, I.; Dréan, A.; Song, F.; Aleksandrov, R.; Harrell, M.I.; Menon, M.; Brough, R.; Campbell, J.; et al. Genome-wide and high-density CRISPR-Cas9 screens identify point mutations in PARP1 causing PARP inhibitor resistance. Nat. Commun. 2018, 9. [CrossRef]

71. Mweempwa, A.; Wilson, M.K. Mechanisms of resistance to PARP inhibitors-An evolving challenge in oncology. Cancer Drug Resist. 2019, 608-617. [CrossRef] 
72. Haynes, B.; Murai, J.; Lee, J.M. Restored replication fork stabilization, a mechanism of PARP inhibitor resistance, can be overcome by cell cycle checkpoint inhibition. Cancer Treat. Rev. 2018, 71, 1-7. [CrossRef]

73. Yazinski, S.A.; Comaills, V.; Buisson, R.; Genois, M.M.; Nguyen, H.D.; Ho, C.K.; Kwan, T.T.; Morris, R.; Lauffer, S.; Nussenzweig, A.; et al. ATR inhibition disrupts rewired homologous recombination and fork protection pathways in PARP inhibitor-resistant BRCA-deficient cancer cells. Genes Dev. 2017, 31, 318-332. [CrossRef]

74. Young, L.A.; O'Connor, L.O.; de Renty, C.; Veldman-Jones, M.H.; Dorval, T.; Wilson, Z.; Jones, D.R.; Lawson, D.; Odedra, R.; Maya-Mendoza, A.; et al. Differential activity of ATR and Wee1 inhibitors in a highly sensitive subpopulation of DLBCL linked to replication stress. Cancer Res. 2019, 79, 3762-3775. [CrossRef]

75. Gadhikar, M.A.; Zhang, J.; Shen, L.; Rao, X.; Wang, J.; Zhao, M.; Kalu, N.N.; Johnson, F.M.; Byers, L.A.; Heymach, J.; et al. CDKN2A/p16 Deletion in Head and Neck Cancer Cells Is Associated with CDK2 Activation, Replication Stress, and Vulnerability to CHK1 Inhibition. Cancer Res. 2018, 78, 781-797. [CrossRef] [PubMed]

76. MedlinePlus, National Library of Medicine. Available online: https://medlineplus.gov/genetics/gene/cdkn2a/ (accessed on 22 October 2020).

77. Bakr, A.; Oing, C.; Köcher, S.; Borgmann, K.; Dornreiter, I.; Petersen, C.; Dikomey, E.; Mansour, W.Y. Involvement of ATM in homologous recombination after end resection and RAD51 nucleofilament formation. Nucleic Acids Res. 2015, 43, 3154-3166. [CrossRef]

78. Srivastava, M.; Nambiar, M.; Sharma, S.; Karki, S.S.; Goldsmith, G.; Hegde, M.; Kumar, S.; Pandey, M.; Singh, R.K.; Ray, P.; et al. An inhibitor of nonhomologous end-joining abrogates double-strand break repair and impedes cancer progression. Cell 2012, 151, 1474-1487. [CrossRef]

79. Denizot, F.; Lang, R. Rapid colorimetric assay for cell growth and survival. Modifications to the tetrazolium dye procedure giving improved sensitivity and reliability. J. Immunol. Methods 1986, 89, 271-277. [CrossRef]

80. Klaude, M.; Eriksson, S.; Nygren, J.; Ahnstrom, G. The comet assay: Mechanisms and technical considerations. Mutat. Res. 1996, 363, 89-96. [CrossRef]

81. Tice, R.R.; Andrews, P.W.; Singh, N.P. The single cell gel assay: A sensitive technique for evaluating intercellular differences in DNA damage and repair. Basic Life Sci. 1990, 53, 291-301. [CrossRef]

82. Olive, P.L.; Banáth, J.P. The comet assay: A method to measure DNA damage in individual cells. Nat. Protoc. 2006, 1, 23-29. [CrossRef]

83. Rueden, C.T.; Schindelin, J.; Hiner, M.C.; DeZonia, B.E.; Walter, A.E.; Arena, E.T.; Eliceiri, K.W. ImageJ2: ImageJ for the next generation of scientific image data. BMC Bioinform. 2017, 18, 529. [CrossRef]

84. Kurt De Vos; University of Sheffield, Academic Neurology Image J, Cell Counter Plugin. Available online: https://imagej.nih.gov/ij/plugins/cell-counter.html (accessed on 22 October 2020).

85. Available online: https://worddisk.com/wiki/Microsoft_Excel/ (accessed on 4 November 2020).

86. Navendu, V. Online Web Statistical Calculators for Categorical Data Analysis. 2016. Available online: astatsa.com (accessed on 22 October 2020).

Publisher's Note: MDPI stays neutral with regard to jurisdictional claims in published maps and institutional affiliations.

(C) 2020 by the authors. Licensee MDPI, Basel, Switzerland. This article is an open access article distributed under the terms and conditions of the Creative Commons Attribution (CC BY) license (http://creativecommons.org/licenses/by/4.0/). 